\title{
Sequence stratigraphy of fluvial to shallow-marine deposits: The case of the early Permian Rio Bonito Formation, Paraná Basin, southernmost Brazil
}

\author{
Ricardo Maahs $^{1 *}$ (D), Juliano Küchle ${ }^{1}$ (D), Claiton Marlon dos Santos Scherer ${ }^{1}$ (D), Renata dos Santos Alvarenga ${ }^{1}$ (D)
}

\begin{abstract}
This study presents new sedimentology data and attempts to understand coastal processes, sedimentary dynamics and stratigraphic patterns of the Rio Bonito Formation (early Permian) in Paraná Basin, southern Brazil. The study was performed based on the description of five cores, located in a small-scale area — São Gabriel City — in Rio Grande do Sul State, southern Brazil. Eighteen facies were described and grouped into nine facies associations. Later, these facies associations were then grouped into three depositional systems: fluvial, tide-dominated estuary and wave-dominated shallow-marine depositional systems. A paleoenvironmental evolution is proposed using three block diagrams showing the paleoenvironmental stage (S1, S2, and S3). S1 contains the oldest part of the sedimentary record with predominance of fluvial system deposits, S2 comprises dominantly estuarine system deposits, and S3 is mostly composed of shallow-marine deposits. Stratigraphic framework showed a general retrogradacional tendency, with thickness variations along the systems tracts that allowed for the construction of a curve of accommodation changes to the Rio Bonito Formation in the region of São Gabriel during the early Permian. This study contributes to a better understanding of the fluvial discharges, tidal and oscillatory (wave) currents and their interactions and dominances along stratigraphic records of coastal deposits.
\end{abstract}

KEYWORDS: Sedimentology; estuarine deposits; coastal deposits; tide; wave; Guatá Group.

\section{INTRODUCTION}

One of the most studied units of the Paraná Basin, in southern Brazil, is the Rio Bonito Formation, due to the ubiquitous presence of coal beds and the potential of the formation as analogue for hydrocarbon reservoirs in coastal sandstones.

Several works have already described the Rio Bonito Formation; however, its depositional environments (e.g., Schneider et al. 1974, Milani 1997, Lavina \& Lopes 1987, Holz 2003) and stratigraphic framework (e.g., Holz 1995, Lopes 2004, Holz et al. 2010) are frequently revaluated.

In the early 2000's, several authors considered the Rio Bonito (coastal deposits) and Palermo (shallow-marine deposits) formations as coeval units (e.g., Holz et al. 2006); once that shallow-marine deposits overlay coastal ones in some areas, and in others they are interfingered.

$\mathrm{Holz}$ (2003) proposed a depositional model for the formation of a wave and tide influenced estuary evolving to a barrier-lagoon depositional system, in Candiota, southern portion

\footnotetext{
Supplementary data

Supplementary data associated with this article can be found in the online version: Supplementary Figure A1 and Supplementary Figure A2.

${ }^{1}$ Universidade Federal do Rio Grande do Sul - Porto Alegre (RS), Brazil. E-mails: maahs.geologia@gmail.com, juliano.kuchle@ufrgs.br, claiton.scherer@ufrgs.br, renatalvarenga@yahoo.com.br

${ }^{*}$ Corresponding author.
}

(C) 2019 The autors. This is an open access article distributed under the terms of the Creative Commons license. of Rio Grande do Sul State, southern Brazil. This proposal is often used as a regional depositional model for the Rio Bonito Formation - for example, Reis (2007), who interpreted successions of the Rio Bonito Formation in São Gabriel area, also in Rio Grande do Sul State, as a similar depositional setting proposed by Holz (2003).

The current point of discussion is related to whether regional proposals for the Rio Bonito Formation depositional model and stratigraphic framework are applicable to its diverse regions of occurrence. It appears challenging to apply those regional proposals to all local variations of the formation. Furthermore, a similar depositional scenario in all loci of the Rio Bonito Formation is very unlikely, since the unit is exposed along the eastern border of the Paraná Basin (roughly $2,170 \mathrm{~km}$ ) and coastal environments are erosive - at several scales - and very dynamic. This continuous reassessment of the Rio Bonito Formation depositional and evolutionary models reflects the state of art of decades of scientific production. The understanding of facies associations and depositional systems in coastal deposits advanced widely along the last four decades, and the usual diagnostics based exclusively on tidal or wave occurrences are now based on robust analysis (e.g., from Roep et al. 1979, to Plint 2010).

We present new sedimentological data that permit to test the depositional scenario of Holz (2003) and Reis (2007). From these new data, the main objective of this paper was to reassess the depositional processes, and to develop a high-resolution stratigraphic evolutionary model for a small area of the Rio Bonito Formation, in the city of São Gabriel, Brazil (Fig. 1). 
This detailed analysis allows new data and interpretations about coastal processes, sedimentary dynamics and stratigraphic patterns, mainly discussing tide and wave dominance and interplay on clastic coasts, and the preservation potential of facies associations related to these processes. This data set of collecting/interpretation contributes to rules/exception of scientific knowledge on coastal sedimentology, not only for the Paraná Basin and Permian time, but as "a small brick on the wall" of sedimentological understanding of coastal systems. Also, the relationship between coastal processes dominance and the space ratio evolution along sedimentary deposition define a curve of accommodation changes through time.

\section{GEOLOGICAL SETTING}

Located in the central-eastearn portion of the South American Platform, the Paraná Basin has an area of approximately 1,700,000 km² (Fig. 2), extending from central-southern Brazil to northwestern Uruguay, and parts of Paraguay and Argentina (Holz et al. 2010). The sedimentary fill of this basin was conditioned by tectonic-eustatic cycles linked to the Paleozoic and Mesozoic tectonic evolution of Western Gondwana (Zalán et al. 1990, Milani et al. 1994, Holz et al. 2010). The entire stratigraphic record of the Paraná Basin is up to 7,500 $\mathrm{m}$ in thickness and was deposited in a time interval that encompasses $385 \mathrm{Ma}$, between Late Ordovician and Late Cretaceous time (Milani et al. 2007).

Milani (1997) subdivided the stratigraphic record of the Paraná Basin into six second-order supersequences (Fig. 2):

i. Rio Ivaí (Ordovician-Silurian);

ii. Paraná (Devonian);

iii. Gondwana I (Late Carboniferous - Early Triassic);

iv. Gondwana II (Middle Triassic — Late Triassic); v. Gondwana III (Late Jurassic - Early Cretaceous); vi. Bauru (Late Cretaceous).

According to Milani (1997) and Milani et al. (2007), the Gondwana I Supersequence is composed of the Itararé Group and Aquidauana Formation (Goiás State), the Guatá Group (that includes the Rio Bonito and Palermo formations), followed by the Passa Dois Group and the Pirambóia and Sanga do Cabral Formations (Fig. 3). The Guatá Group was deposited during the Permian transgression (Lavina \& Lopes 1987) and after the deposition of the glacial and post-glacial deposits of the Itararé Group. The Rio Bonito Formation is constituted mainly of quartzofeldspathic and quartzose sandstones, siltstones, carbonaceous shales and coal (Schneider et al. 1974). The most representative sedimentary structures in the Rio Bonito Formation are planar-cross- and plano-parallel-bedding. Sandstones of the Rio Bonito Formation ubiquitously display flaser, mud drapes, wavy bedding, and hummocky cross-stratification (e.g., Lopes 2004, Holz 2003).

The Rio Bonito Formation was divided by Schneider $e$ t al. (1974) into three members that, from base to top, are (Fig. 3): i. Triunfo (coastal and fluvial sandstones);

ii. Paraguaçu (marine mudstones and fine-grained sandstones); iii. Siderópolis (coastal and fluvial sandstones).

These members are easily recognizable in Santa Catarina State, southern Brazil. However, in the southernmost part of the Paraná Basin, comprising the study area (Rio Grande do Sul State, southern Brazil), the Rio Bonito Formation has not been subdivided into members (Holz et al. 2006, 2010).

According to Holz and Carlucci (2000), the Rio Bonito Formation represents coastal deposits overlain by shallow-marine deposits of the Palermo Formation. However, according

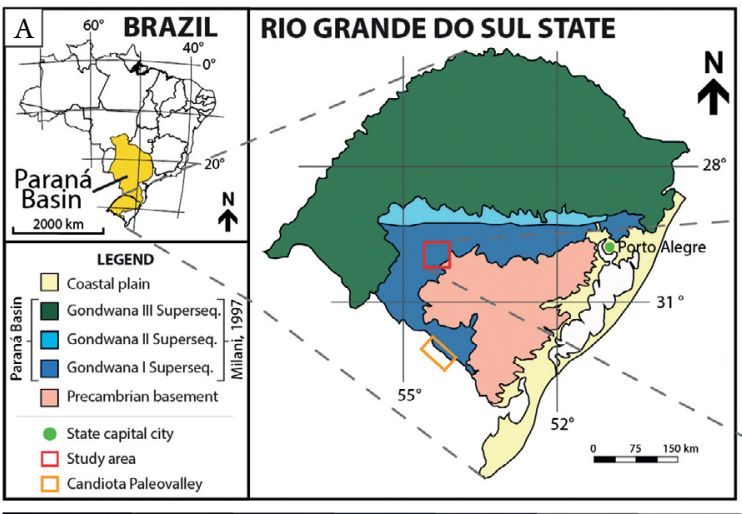

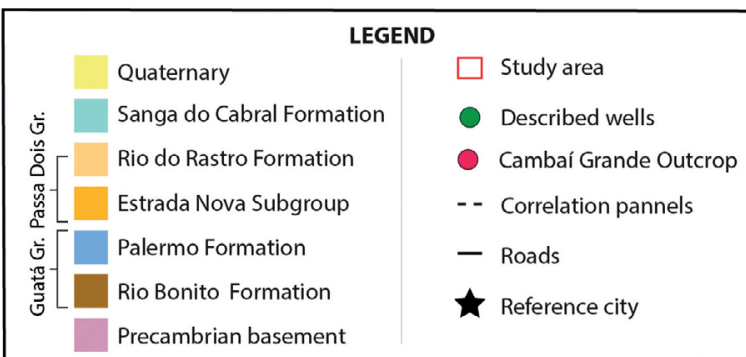

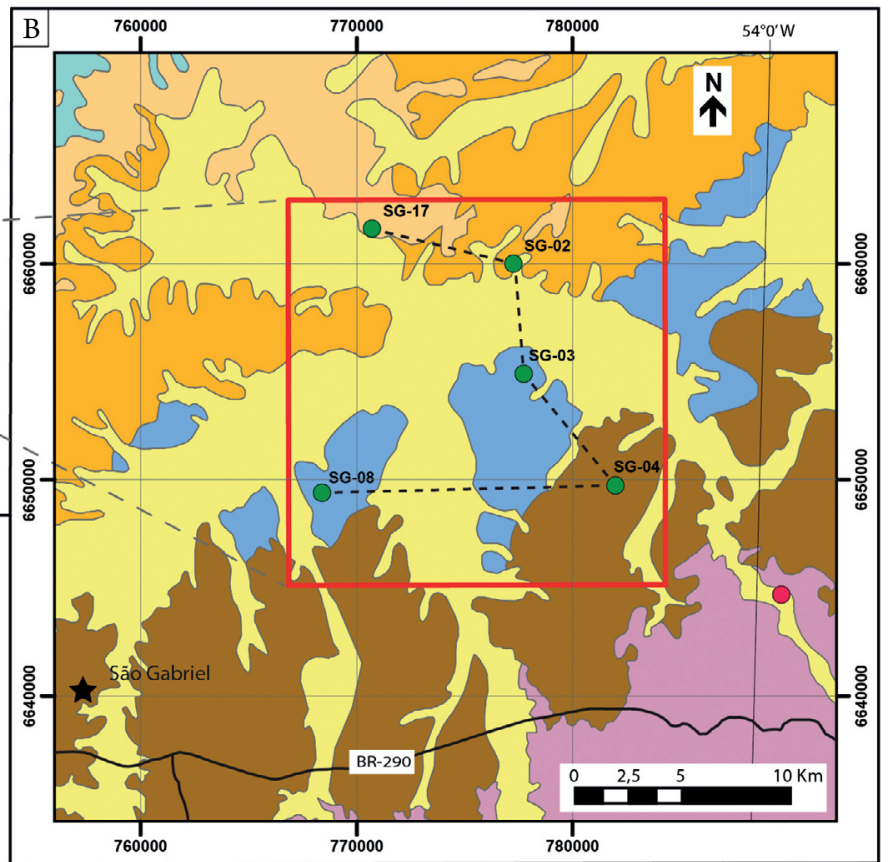

Figure 1. (A) Location of the Paraná Basin in central-southern Brazil and in the Rio Grande do Sul State, southern Brazil. (B) Geological map of the Paraná Basin and crystalline Precambrian basement (modified from Wildner et al. 2008) showing the study area (red rectangle) with the location of the described wells (green circles) and indication of the correlation section used for the stratigraphic framework. 


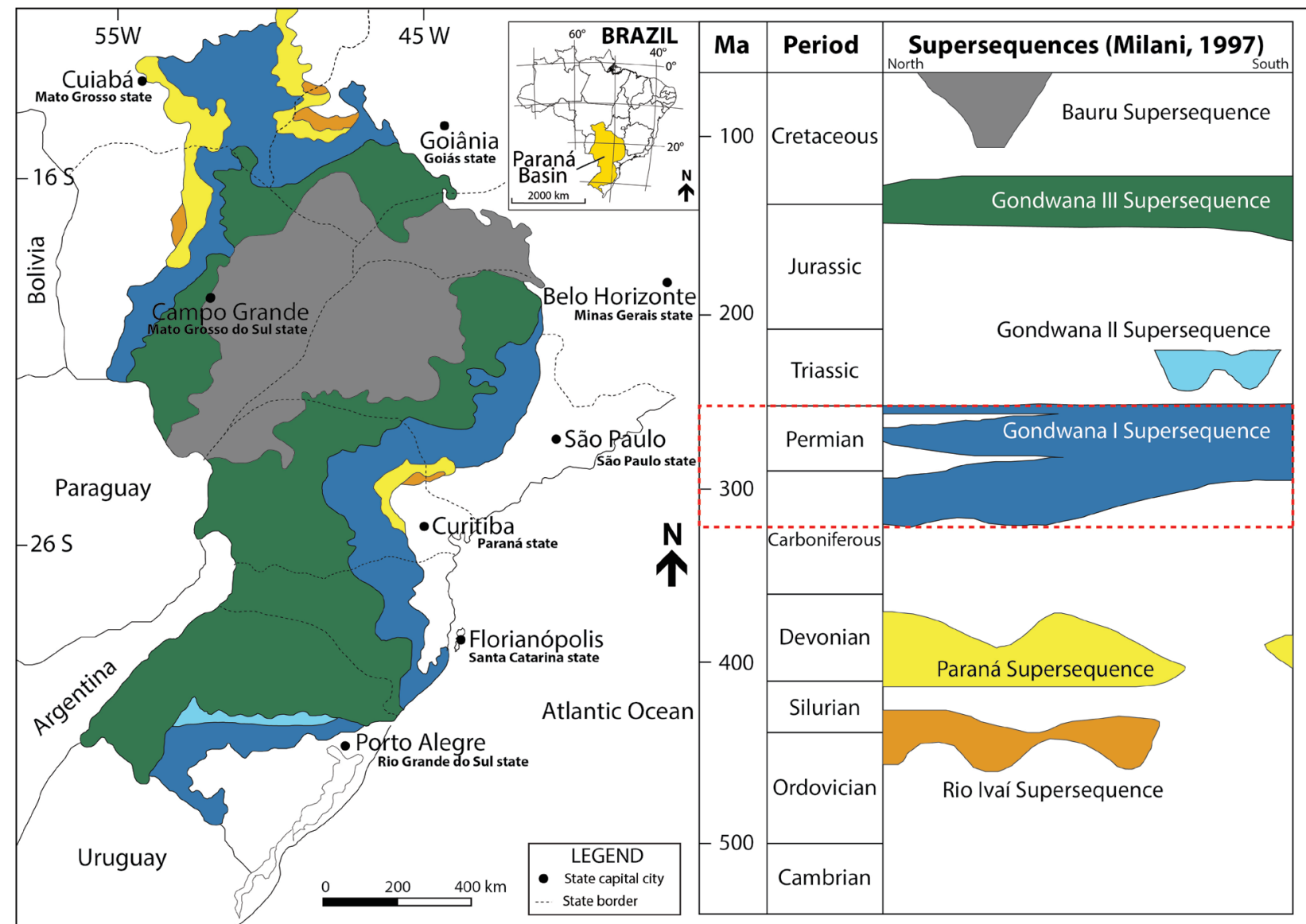

Figure 2. Simplified geological map of the Paraná Basin showing the distribution of the Supersequences (according to Milani 1997) and the simplified stratigraphic chart of an approximate north-south section (modified after Milani et al. 2007 and Holz et al. 2010). Each Supersequence is represented by the same color in the map and stratigraphic chart. Gondwana I Supersequence interval, that includes the Guatá Group, is highlighted by the red dashed line rectangle.

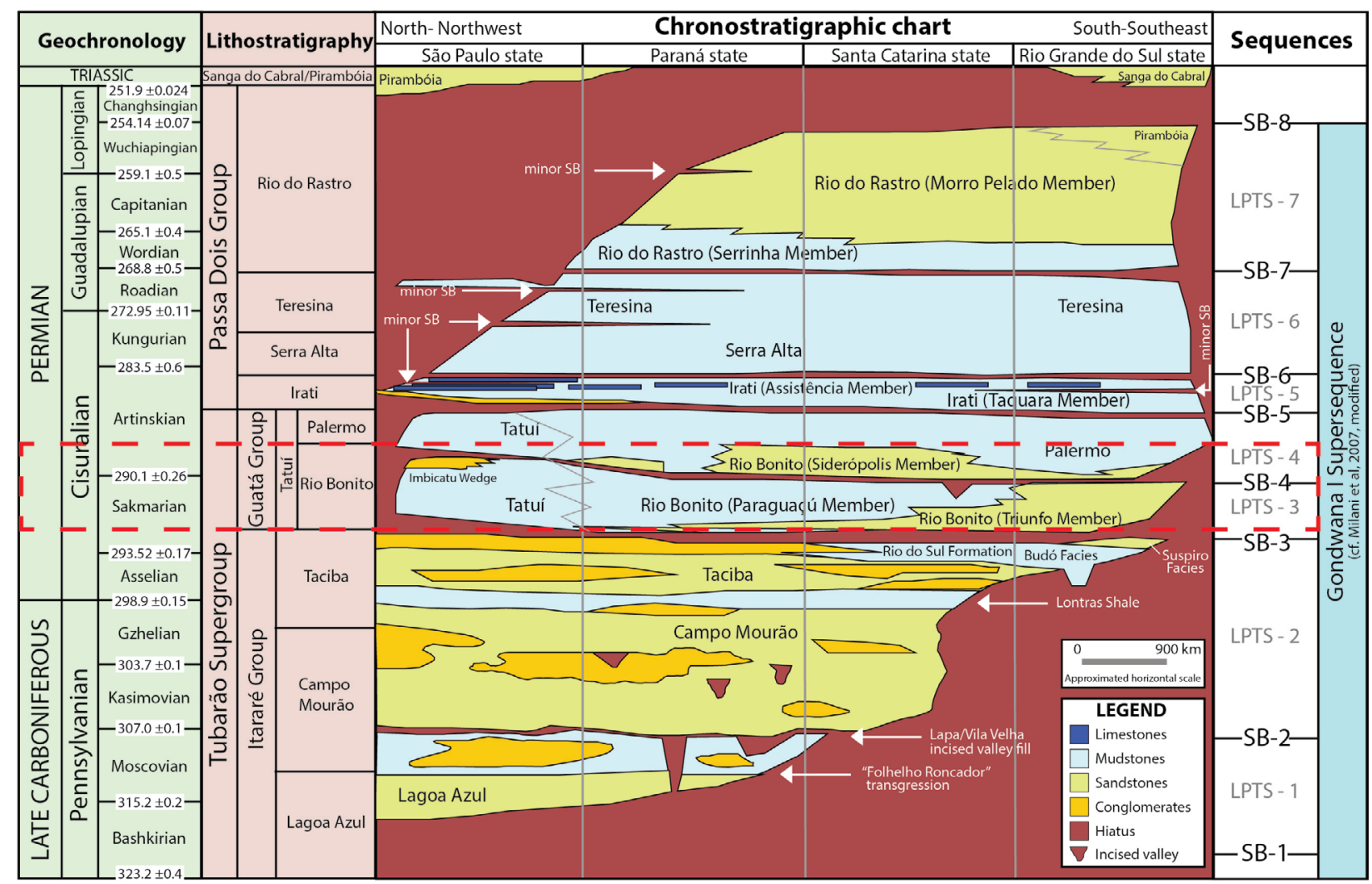

Figure 3. The stratigraphic chart of the late Carboniferous-early Permian succession of the eastern border of the Paraná Basin (after Holz et al. 2010, modified; permission from Elsevier obtained using the Copyright Clearance Center's Rightslink ${ }^{\circledR}$ ). The Rio Bonito Formation interval is highlighted by the red dashed line rectangle with ages between early Sakmarian and middle Artinskian. 
to Holz et al. (2010), the interaction between these formations is complex, because most of the time they were deposited simultaneously, causing cycles and interdigitations of these units. Holz et al. (2010), in "the stratigraphic chart of the Late Carboniferous/Permian succession of the eastern border of the Paraná Basin” (Fig. 3), recognized seven Late Paleozoic Third-Order Sequences (LPTS), each of which limited by sequence boundaries (SB). LPTS-3 and LPTS-4 include the Rio Bonito Formation. In Rio Grande do Sul State, this formation occurs mainly within LPTS-3, between SB-3 and SB-4, and at the base of LPTS-4, immediately SB-4.

The Guatá Group comprises formations that were deposited during the early Permian, as indicated by palynological studies (Daemon \& Quadros 1970, Souza \& Marques-Toigo 2005, Mori et al. 2012). As synthesized by Holz et al. (2010), the Rio Bonito Formation was deposited between early Sakmarian and middle Artinskian time (Fig. 3). Although this is not the purpose of this work, it is important to highlight that recent studies have introduced new isotopic ages based on several $\mathrm{U}-\mathrm{Pb}$ analytical techniques on zircons crystals (SHRIMP, e.g., Rocha-Campos et al. 2006; LA-ICP-MS, e.g., Cagliari et al. 2014, 2016; TIMS, e.g., Griffis et al. 2018) for the limit between the Itararé and the Guatá Groups, showing that Rio Bonito Formation deposition began in the early Asselian (close to the Carboniferous-Permian boundary), instead of early Sakmarian (Holz et al. 2010), in the southern part of the Paraná Basin.

\section{MATERIALS AND METHODS}

In this work, data from the Rio Bonito Formation were acquired through detailed description and gamma-ray logs of five borehole cores (Tab. 1) from the northeast of São Gabriel City (Fig. 1). The boreholes were obtained in the 1970's and 1980's coal prospection program in the Rio Bonito Formation. Currently, the cores are under the care of the Brazilian Geological Survey (CPRM) in the Caçapava do Sul Litotheque. Both borehole cores and gamma-ray logs were provided by CPRM, which gave us permission to describe the cores and publish the results. We described a total thickness of $401.75 \mathrm{~m}$ of core samples on a scale of $1: 50$, spatially distributed over an area of $252 \mathrm{~km}^{2}$ (Fig. 1). Sedimentary facies were classified on the basis of grain-size and sedimentary structures, following the methodology and nomenclature adapted from Miall (2006). The bioturbation was described by size, frequency (rare, occasional, common and very common) and

Table 1. Location data of the described boreholes (SAD69 UTM reference coordinate system).

\begin{tabular}{lcccc}
\hline Borehole & Zone & UTM X & UTM Y & Elevation \\
\hline SG-02 & 21J & $777350 \mathrm{mE}$ & $6660000 \mathrm{mS}$ & $75 \mathrm{~m}$ \\
\hline SG-03 & $21 \mathrm{~J}$ & $777550 \mathrm{mE}$ & $6654900 \mathrm{mS}$ & $85 \mathrm{~m}$ \\
\hline SG-04 & $21 \mathrm{~J}$ & $782000 \mathrm{mE}$ & $6649750 \mathrm{mS}$ & $130 \mathrm{~m}$ \\
\hline SG-08 & $21 \mathrm{~J}$ & $768400 \mathrm{mE}$ & $6649400 \mathrm{mS}$ & $90 \mathrm{~m}$ \\
\hline SG-17 & $21 \mathrm{~J}$ & $770800 \mathrm{mE}$ & $6661600 \mathrm{mS}$ & $105 \mathrm{~m}$ \\
\hline
\end{tabular}

intensity - bioturbation index (i.e. $\mathrm{BI}=1-$ discrete traces to $\mathrm{BI}=6$ - homogenized sediments), according to Bann et al. (2008). Genetically related facies were grouped into facies associations, which were arranged in depositional systems (Collinson \& Thompson 1989). Finally, we propose a depositional model illustrated by using three block diagrams representing the paleoenvironmental evolution stages (according to Shanmugam et al. 2000) of the study area. The stratigraphic framework was developed based on the assumptions of the sequence stratigraphy sensu Catuneanu (2006) and Catuneanu et al. (2009). A correlation section between the five cores was constructed for the identification of key stratigraphic surfaces and system tracts.

\section{RESULTS}

\section{Sedimentary facies}

We recognized 18 facies. Their code, description and interpretation are synthesized in Table 2, based on Miall (2006), and illustrated in Figures 4 and 5.

\subsection{Facies Associations}

The facies were grouped into nine facies associations that represent the interplay of different characteristic sedimentary processes of a certain sedimentary environment or subenvironment of the Rio Bonito Formation. The facies associations are:

i. gravity-flow-deposits;

ii. fluvial channel;

iii. overbank;

iv. tidal mud flat;

v. tidal sand flat;

vi. tidal sand bars;

vii. upper shoreface;

viii. middle shoreface;

ix. lower shoreface-shelf transition (Tab. 3).

The relative proportion of facies associations is shown in Supplementary A1 and facies occurrence in each facies association is presented in Supplementary A2.

\section{Gravity-flow-deposits facies association}

Description: This facies association represents $3 \%$ of the stratigraphic record (Supplementary A). It is associated to layers interpreted as gravity-flow-deposits in the lower portions of SG-08 and SG-02 wells. Their thicknesses vary from 1 to $3.2 \mathrm{~m}$. This facies association comprises massive matrix-supported conglomerates to locally gravelly mudstones ( $\mathrm{Gmm}$ ), massive clast-supported conglomerates locally with imbricated granules (GCm), and massive sandstones with dispersed granules and pebbles of quartz and lithic fragments $(\mathrm{Sm})$ (Figs. 6A, 6B, 6C and 6D; Tab. 3; Supplementary B).

Interpretation: Gravity-flow-deposits are interpreted as debris flows and stream flows, and occur at the bottom of the described cores. In addition to the indicative granulometry, the interpretation of gravity-flow-deposits is related to layer thickness and to the dominantly clayey matrix (facies Gmm) 
Table 2. Summary of facies observed in the Rio Bonito Formation.

\begin{tabular}{|c|c|c|}
\hline ir code & Description & Interpretation \\
\hline $\mathrm{Gcm}$ & $\begin{array}{l}\text { Massive or crudely-stratified clast-supported to sandy matrix-supported } \\
\text { conglomerates with a coarse sandstone "matrix", composed of subangular to } \\
\text { subrounded granules and pebbles of polymitic fragments (gneiss, schist, granite, } \\
\text { quartz and feldspars). Millimetric plant fragments occur locally. Beds range from } \\
10 \mathrm{~cm} \text { to } 1 \mathrm{~m} \text { in thickness, frequently with an abrupt base. Fig. 4A. }\end{array}$ & $\begin{array}{l}\text { Pseudoplastic debris flow (inertial bedload, } \\
\text { turbulent flow); rarely, longitudinal } \\
\text { bedforms (Miall 2006). }\end{array}$ \\
\hline Gmm & $\begin{array}{l}\text { Massive matrix-supported conglomerates (locally gravelly mudstones) composed } \\
\text { of a mudstone matrix with dispersed subangular to subrounded granules and } \\
\text { pebbles of polymitic fragments (gneiss, schist, granite, quartz and feldspars). } \\
\text { Dish and pillar structures and diagenetic sideritic (?) nodules }(<1 \mathrm{~cm}) \text { can occur. } \\
\text { Beds range from } 5 \mathrm{~cm} \text { to } 8 \mathrm{~m} \text { in thickness. Fig. } 4 \mathrm{~B} \text {. }\end{array}$ & $\begin{array}{l}\text { Plastic debris flow (high-strength, viscous) } \\
\text { (Miall 2006). }\end{array}$ \\
\hline $\mathrm{Gm}_{\mathrm{i}}$ & $\begin{array}{l}\text { Massive or with faint horizontal lamination coarse-grained sandstones to clast- } \\
\text { supported conglomerates, poorly to moderately-sorted, composed of millimetric } \\
\text { to centimetric intraclasts and subangular granules of immature composition } \\
\text { (quartz, feldspars and lithic fragments). Beds range from } 1 \text { to } 35 \mathrm{~cm} \text { in thickness } \\
\text { and may locally present normal grading. Abrupt and erosive top and base and } \\
\text { heterolithic intercalations are common. Fig. 4C. }\end{array}$ & $\begin{array}{l}\text { Reworking of sediments with some } \\
\text { lithification in high hydrodynamic } \\
\text { conditions by strong subaqueous tractive } \\
\text { current (lag deposits) (Holz, 2003; Plint, } \\
\quad \text { 2010; Zecchin et al., 2017). }\end{array}$ \\
\hline
\end{tabular}

Very fine- to very coarse-grained, moderately to poorly-sorted massive sandstones, usually presenting normal grading. Centimetric to millimetric bioturbation (BI: 1 to 4; vertical, subvertical and horizontal excavations), dish and pillar structures and millimetric mud films are usual features. Dispersed subangular granules and pebbles of quartz and lithic fragments, millimetric plant fragments, mud intraclasts $(<4 \mathrm{~cm})$, diagenetic sideritic (?) nodules $(<1$ $\mathrm{cm}$ ) and synsedimentary folds occur locally. Beds range from $10 \mathrm{~cm}$ to $2 \mathrm{~m}$ in thickness and rarely present an abrupt base contact. Fig. 4D.

Very coarse- to fine-grained, poorly to well-sorted sandstones with crossstratification, locally presenting normal grading. Dispersed subangular granules and pebbles of quartz and lithic fragments, millimetric mud films, $(<3 \mathrm{~cm})$, plant fragments $(<1 \mathrm{~cm})$ and diagenetic sideritic (?) nodules $(<1 \mathrm{~cm})$ occur locally. Mud intraclasts and synsedimentary folds are rare. Beds range from $15 \mathrm{~cm}$ to $9 \mathrm{~m}$ in thickness and locally present an abrupt basal contact. Fig. 4E.

Coarse- to fine-, rarely very coarse-grained, poorly to well-sorted sandstones with cross-stratification, commonly presenting normal grading. Regular to irregular millimetric single mud drapes (rarely double mud drapes), mud intraclasts $(<4$

$\left.\mathrm{Sc}_{\mathrm{d}} \quad \mathrm{cm}\right)$ and plant fragments $(<1 \mathrm{~cm})$ are usual features. Millimetric to centimetric bioturbation (BI: 1; horizontal excavation) and dish and pillar structures are rare. Beds range from $15 \mathrm{~cm}$ to $0.5 \mathrm{~m}$ in thickness and rarely present an abrupt contact. Fig. 4F.

Rapid deposition of hyperconcentrated flows, fluidization, intensive bioturbation and high compaction during diagenesis (Miall 2006).

Migration of subaqueous sandy dunes in unidirectional lower flow regime (Allen 1963, Collinson et al. 2006).

Alternating traction process with migration of subaqueous sandy dunes in lower flow regime and deposition by settling down of suspensed load in standing water (Visser 1980).

Fine-, rarely medium-grained, moderately to well-sorted sandstones presenting hummocky cross-stratification. Centimetric to millimetric bioturbations (BI: 1 to

Shcs 6; horizontal and vertical excavations) are common and beds range from $20 \mathrm{~cm}$
to $9.05 \mathrm{~m}$ in thickness. Fig. 4G.

Shcs 6; horizontal and vertical excavations) are common and
to $9.05 \mathrm{~m}$ in thickness. Fig. 4G.
Fine- to medium-grained, moderately to well-sorted sandstones with swaley Sscs cross-stratification, locally presenting normal grading. Centimetric mud films are common and beds range from $20 \mathrm{~cm}$ to $7.4 \mathrm{~m}$ in thickness. Fig. $4 \mathrm{H}$.
Settling of suspended sediments under low energy oscillatory-dominant, combined flow (distal tempestite deposition) (Harms et al. 1975, Dumas \& Arnott 2006).

Settling of suspended sediments under high-energy oscillatory-dominant, combined flow (proximal tempestite deposition as amalgamated hummocky cross-stratification deposit) (Harms et al. 1975, Dumas \& Arnott 2006)

Fine- to medium-, rarely very fine-grained, poorly to well-sorted sandstones presenting horizontal to low angle cross-stratification. Millimetric plant fragments, mud intraclasts and discontinuous mud films are common and millimetric to centimetric bioturbations (BI: 2; vertical excavations) are rare. Beds range from $10 \mathrm{~cm}$ to $2.1 \mathrm{~m}$ in thickness. Fig. 4I.

Fine- to medium-grained, moderately to well-sorted sandstones presenting unidirectional, rarely bidirectional (proportion of $1 / 10$ ) ripple cross-lamination. Millimetric mud films and plant fragments can occur. Beds range from $15 \mathrm{~cm}$ to $1.5 \mathrm{~m}$ in thickness. Fig. 4J.

Fine- to medium-grained, moderately- to well-sorted sandstones presenting unidirectional, rarely bidirectional (proportion of $1 / 10$ ), ripple cross-lamination and regular to irregular millimetric single mud drapes (rarely double mud drapes). Millimetric plant fragments and bioturbation (BI: 2 to 3; mostly horizontal excavations) can occur. Beds range from $55 \mathrm{~cm}$ to $1.6 \mathrm{~m}$ in thickness. Fig. 4k.

Fine-, rarely medium- or coarse-grained, moderately to well-sorted sandstones presenting wave- (rarely combined) ripple cross-lamination. Millimetric to centimetric mud films are common features and centimetric to millimetric
Attenuated bedforms in transition between lower and upper flow regime (Best \&

Migration of subaqueous ripples in unidirectional (rarely anisotrophic bidirectional) lower flow regime (Allen 1963, Miall 2006).

Alternating traction process with migration of subaqueous ripples in unidirectional (rarely anisotrophic bidirectional) lower

flow regime and deposition by settling down of suspensed load in standing water (Visser 1980).

Symmetrical (or asymmetrical) ripples in oscillatory (or oscillatory and traction) lower flow regime (Walker \& Plint 1992, Clifton 2006). Bridge 1992, Miall 2006). sideritic (?) nodules $(<1 \mathrm{~cm})$ and millimetric mud intraclasts may occur. Beds range from $10 \mathrm{~cm}$ to $2.35 \mathrm{~m}$ in thickness. Fig. $4 \mathrm{~L}$. 
Table 2. Continuation.

\begin{tabular}{|c|c|c|}
\hline ir code & Description & Interpretation \\
\hline $\mathrm{Hr}$ & $\begin{array}{l}\text { Heterolithic intercalations of very fine-grained sandstones with mudstones } \\
\text { varying from wavy, lenticular to flaser bedding. Occurrence of unidirectional } \\
\text { ripple cross-lamination in sandy portions and thin parallel lamination in muddy } \\
\text { levels. Millimetric to centimetric bioturbations (BI: } 1 \text { to } 4 \text {; mostly horizontal } \\
\text { excavations), plant fragments }(<1 \mathrm{~cm}) \text {, diagenetic sideritic }(?) \text { nodules }(<1 \mathrm{~cm}) \\
\text { and dish and pillar structures are common features. Beds range from } 15 \mathrm{~cm} \text { to } \\
2.75 \mathrm{~m} \text { in thickness. Fig. 5A. }\end{array}$ & $\begin{array}{l}\text { Alternating traction process with } \\
\text { subaqueous ripples in unidirectional lower } \\
\text { flow regime and deposition by decantation } \\
\text { of suspended load (Dalrymple 2010). }\end{array}$ \\
\hline $\mathrm{Hr}_{\mathrm{b}}$ & $\begin{array}{c}\text { Heterolithic intercalations of very fine- to fine-, rarely coarse and medium- } \\
\text { grained sandstones with mudstones varying from wavy, lenticular to flaser } \\
\text { bedding. Bidirectional (proportion of 1/10) ripples cross-lamination in sandy } \\
\text { portions and thin parallel lamination in muddy levels can occur. Millimetric } \\
\text { bioturbations (BI: } 1 \text { to 3; mostly horizontal excavations) are common. Basal } \\
\text { abrupt contact, normal grading and disperse subangular granules and pebbles } \\
\text { of quartz and lithic fragments occur locally. Beds range from } 25 \mathrm{~cm} \text { to } 1.6 \mathrm{~m} \text { in } \\
\text { thickness. Fig. } 5 \mathrm{~B} \text {. }\end{array}$ & $\begin{array}{l}\text { Alternating traction process with } \\
\text { subaqueous ripples in anisotrophic } \\
\text { bidirectional lower flow regime with } \\
\text { deposition by decantation of suspended } \\
\text { load (Dalrymple 2010). }\end{array}$ \\
\hline $\mathrm{Hw}$ & $\begin{array}{l}\text { Heterolithic intercalations of very fine- to fine-grained sandstones with } \\
\text { mudstones varying from wavy, lenticular to flaser bedding. Wave-ripple cross- } \\
\text { lamination (locally combined-ripple cross-lamination) in sandy portions } \\
\text { and thin parallel to wave lamination in muddy levels can occur. Millimetric } \\
\text { bioturbations (BI: } 3 \text { to } 4 \text {; mostly horizontal excavations) are very common and } \\
\text { beds range from } 15 \mathrm{~cm} \text { to } 18.3 \mathrm{~m} \text { in thickness. Fig. } 5 \mathrm{C} \text {. }\end{array}$ & $\begin{array}{l}\text { Alternating oscillatory (sometimes } \\
\text { combined-traction and oscillatory) } \\
\text { process with symmetrical (sometimes } \\
\text { asymmetrical) subaqueous ripples in lower } \\
\text { flow regime and deposition by decantation } \\
\text { of suspended load (Walker \& Plint 1992, } \\
\text { Clifton 2006). }\end{array}$ \\
\hline Fm & $\begin{array}{l}\text { Massive, medium to dark gray mudstones, locally in blocks and presenting } \\
\text { incipient lamination. Plant fragments }(0.2 \text { to } 2 \mathrm{~cm}) \text { with variable distribution are } \\
\text { common fratures and beds range from } 30 \mathrm{~cm} \text { to } 4.8 \text { min thickness. Fig. 5D. }\end{array}$ & $\begin{array}{l}\text { Lack of lamination due to (i) flocculation } \\
\text { of clay suspension or (ii) loss of lamination } \\
\text { associated intensive bioturbation or burial } \\
\text { compaction (Miall 2006, Foix et al. 2013). }\end{array}$ \\
\hline $\mathrm{Fl}$ & $\begin{array}{c}\text { Medium grey mudstones with thin parallel lamination, locally interlayered with } \\
\text { millimetric of very fine-grained sandstones. Plant fragments }(0.2 \text { to } 2 \mathrm{~cm}) \text { with } \\
\text { variable distribution are common and dish and pillar structures, synsedimentary } \\
\text { faults and millimetric bioturbations (BI: } 1 \text {; horizontal excavations) are rare. Beds } \\
\text { range from } 5 \mathrm{~cm} \text { to } 1.8 \mathrm{~m} \text { in thickness. Fig. } 5 \mathrm{E} \text {. }\end{array}$ & $\begin{array}{l}\text { Suspension settling, dominantly from } \\
\text { standing water (Rogers \& Astin 1991). }\end{array}$ \\
\hline $\mathrm{C}$ & $\begin{array}{l}\text { Coal, locally reddish black, with beds } \\
\text { ranging from } 5 \text { to } 45 \mathrm{~cm} \text { in thickness. Fig. } 5 \mathrm{~F} \text {. }\end{array}$ & $\begin{array}{l}\text { Decantation of high amounts of organic } \\
\text { matter, mixed with clay minerals (less } \\
\text { proportion), on subaqueous and reducing } \\
\text { conditions; post-depositional oxidizing } \\
\text { conditions (McCabe 1985). }\end{array}$ \\
\hline
\end{tabular}

observed, as well as dispersed immature granules and pebbles of varied origins. Other important facies is $\mathrm{Gcm}$, which is massive and locally contains imbricated granules, suggesting deposition on near-horizontal pavements, either at the top of braided bars or as lags on channel floors (Nemec \& Postma 1993).

\section{Fluvial channel facies association}

Description: This facies association represents $3 \%$ of the stratigraphic record (Suppl. A1). It is only present at the bottom of SG-02, SG-03, SG-04 and SG-08 wells. Its thickness varies from 0.2 to $2.6 \mathrm{~m}$. This association comprises sandstones with cross-stratification $(\mathrm{Sc})$ and massive ones $(\mathrm{Sm})$ (Fig. 6A, 6B and 6E; Tab. 3; Suppl. A2). Subordinately, other facies may occur, such as massive clast-supported conglomerates (GCm) and sandstones with horizontal to low-angle cross-stratification (Sh). These facies may have erosional base and normal grading, in addition to dispersed granules and pebbles of quartz and lithic fragments. Occurrences of mud intraclasts, millimetric mud levels, plant fragments and diagenetic sideritic (?) nodules are common. Further, in Sh and Sm facies, centimetric to millimetric bioturbations (BI: 1-2) occur very locally as vertical and horizontal excavations. Although fining-upward cycles are irregular, they can be well or weak developed in the sandstones of this facies association.
Interpretation: Sc is the main facies of this facies association, indicating unidirectional flow predominance, with the development of dunes. Also, Sm is a relevant facies and, according to Collinson (1996), massive sandstones can occur in fluvial channels as tabular beds (products of rapid deposition from suspension during floods) and lenticular bodies within stratified sandstones (when axes of the channels trend to normal to paleoflow). Fluvial style is driven mainly by the flow and sedimentary processes that operate during seasonal floods (Bridge 2003). The presence of an erosional base and muddy intraclasts leads to the interpretation of an erosional character to these fluvial flows. Due to the small thicknesses of the layers of this facies association and their irregular fining upward patterns, the fluvial channel style was not differentiated.

\section{Overbank facies association}

Description: Overbank represents $7.5 \%$ of the stratigraphic record (Suppl. A1). It is associated with layers interpreted as fluvial channels in the bottom portion of SG-02, SG-03, SG-04 and SG-08 wells. Their thicknesses vary from $5 \mathrm{~cm}$ to $8.8 \mathrm{~m}$. This facies association is mainly composed of mudstones with parallel lamination (Fl), massive mudstones (Fm), heterolithic intercalations of sand and mud - wavy, lenticular and flaser bedding — with unidirectional ripples cross-lamination in 

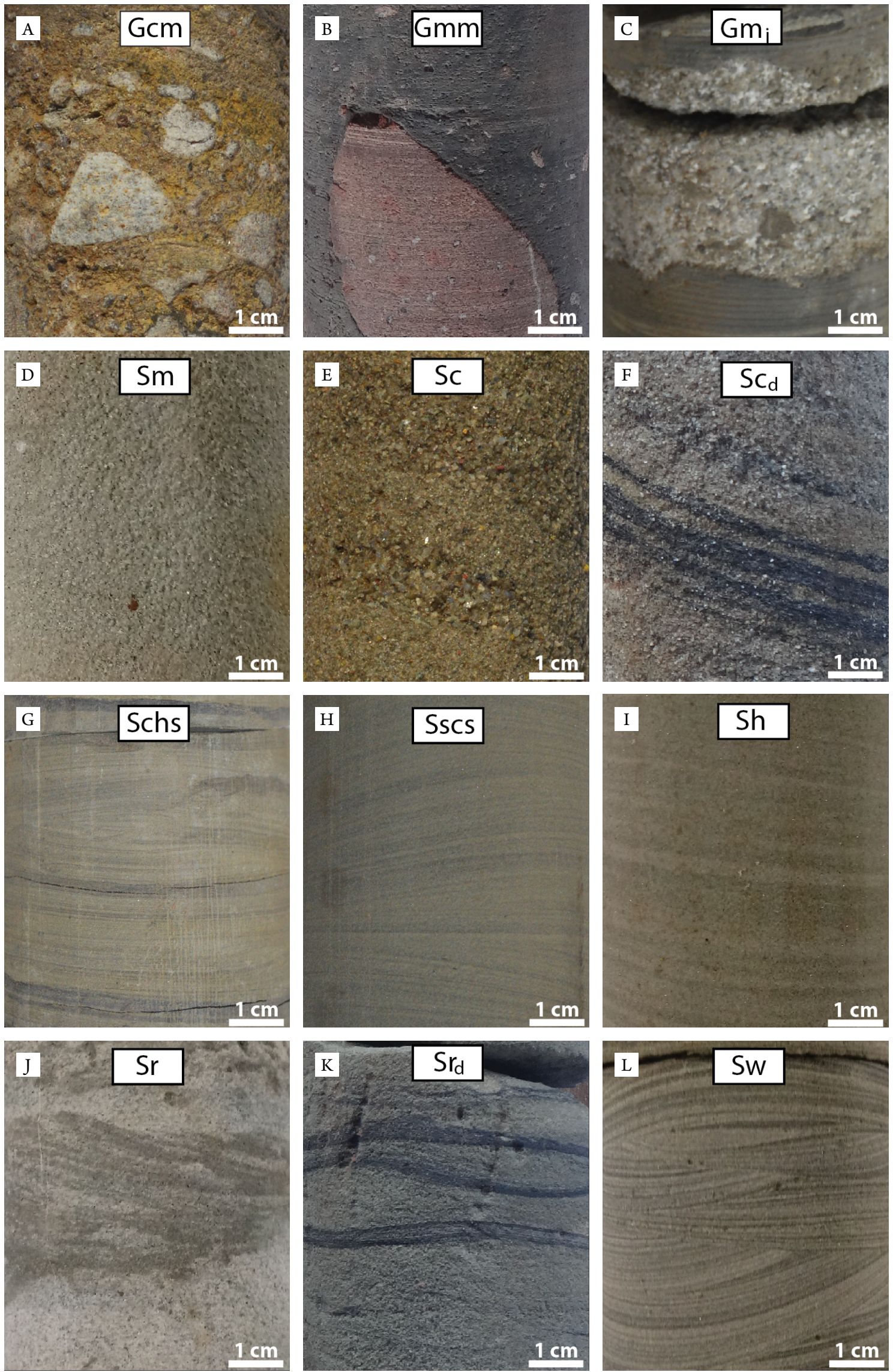

Figure 4. Core photographs of the facies that compose the Rio Bonito Formation in the study area. (A) Massive clast-supported conglomerate (Gcm), 165.9 m, SG-03 well. (B) Massive matrix-supported conglomerate (Gmm), 129.2 m, SG-02 well. (C) Massive or faint bedded coarsegrained sandstone to clast-supported conglomerate with immature composition grains $\left(\mathrm{Gm}_{\mathrm{i}}\right), 280.0 \mathrm{~m}, \mathrm{SG}-17$ well. (D) Massive sandstone (Sm), 113.0 m, SG-03 well. (E) Sandstone with cross-stratification (St), $118.6 \mathrm{~m}, \mathrm{SG}-03$ well. (F) Sandstone with cross-stratification and mud drapes (Std), $72.8 \mathrm{~m}$, SG-02 well. (G) Sandstone with hummocky cross-stratification (Shcs), $70.0 \mathrm{~m}$, SG-08 well. (H) Sandstone with swaley cross-stratification (Sscs), $54.0 \mathrm{~m}$, SG-08 well. (I) Sandstone with horizontal to low-angle cross-stratification (Sh), $83.0 \mathrm{~m}, \mathrm{SG}-03$ well. (J) Sandstone with ripples cross-lamination $(\mathrm{Sr}), 157.0 \mathrm{~m}, \mathrm{SG}-03$ well. $(\mathrm{K})$ Sandstone with ripples cross-lamination and mud drapes $\left(\mathrm{Sr}_{\mathrm{d}}\right)$, 74.4 m, SG-02 well. (L) Sandstone with wave-ripples cross-lamination (Sw), 86.15 m, SG-02 well. 
sandy portions (Hr) and coal (C) (Fig. 6A, 6B and 6F; Tab. 3; Suppl. A2). Unusually, there are also massive sandstone ( $\mathrm{Sm})$, and sandstone with ripples cross-lamination $(\mathrm{Sr})$. It is very common that mudstones and heteroliths of this facies are darker and have many millimetric plant fragments like leaves and stems. Furthermore, bioturbation (BI: 1), as millimetric horizontal excavation, is very rare in the heteroliths and there are occurrences of diagenetic sideritic (?) nodules or fluidized layers.

Interpretation: Overbank sediments comprise floodplain fines, crevasse splay sands, thin channels sandbodies, paleosols and, in some cases, coal (Collinson 1996). In this work, the overbank is predominantly composed of mudstones, evidencing an important floodplain, but besides the fine sedimentation, there are other types of deposits such as heteroliths and sandstones. These litologies indicate a floodplain with frequent breach levees forming crevasse splays deposits. Therefore, these deposits were grouped as an overbank facies association.

\section{Tidal mud flat facies association}

Description: This facies association represents $5.5 \%$ of the stratigraphic record (Suppl. A1). It occurs in SG-02, SG-03, SG-04 and SG-08 wells, with thicknesses varying from 0.8 to $7.6 \mathrm{~m}$. This facies association is composed of heterolithic intercalations - lenticular or wavy bedding - with unidirectional $(\mathrm{Hr})$ and bidirectional $\left(\mathrm{Hr}_{\mathrm{b}}\right)$ ripples cross-lamination in sandy portions, and mudstones with parallel lamination (Fl) (Figs. 7A, 7B, 7C, 7D and 7E; Tab. 3; Suppl.A2). Centimetric beds of massive sandstones rarely occur. Also,

Table 3. Summary of the depositional systems, facies associations and facies proportions identified.

\begin{tabular}{|c|c|c|}
\hline $\begin{array}{l}\text { Depositional } \\
\text { System }\end{array}$ & Facies Association & Facies proportions \\
\hline \multirow{3}{*}{ Fluvial } & Gravity-flow-deposits & $\mathrm{Gmm}, \mathrm{Gcm}, \mathrm{Sm}$ \\
\hline & Fluvial channel & $\mathrm{Sc}, \mathrm{Sm}, \mathrm{Gcm}, \mathrm{Sh}$ \\
\hline & Overbank & $\mathrm{Fl}, \mathrm{Hr}, \mathrm{Fm}, \mathrm{C}, \mathrm{Sm}, \mathrm{Sr}$ \\
\hline \multirow{3}{*}{$\begin{array}{l}\text { Tide- } \\
\text { dominated } \\
\text { estuary }\end{array}$} & Tidal mud flat & $\mathrm{Hr}, \mathrm{Fm}, \mathrm{Fl}, \mathrm{Hr}_{\mathrm{b}}, \mathrm{Sm}$ \\
\hline & Tidal sand flat & $\begin{array}{c}\mathrm{Hr}_{\mathrm{b}}, \mathrm{Sm}, \mathrm{Sr} \\
\mathrm{Hr}, \mathrm{Sr}_{\mathrm{d}}, \mathrm{Sh}, \mathrm{Sc}\end{array}$ \\
\hline & Tidal sand bar & $\begin{array}{c}\mathrm{Sc}_{\mathrm{d}}, \mathrm{Sc}, \mathrm{Sr}_{\mathrm{d}} \\
\mathrm{Sm}, \mathrm{Fl}, \mathrm{Sr}, \mathrm{Sh}, \mathrm{Hr}\end{array}$ \\
\hline \multirow{3}{*}{$\begin{array}{l}\text { Wave- } \\
\text { dominated } \\
\text { shallow- } \\
\text { marine }\end{array}$} & Upper shoreface & Sh, Sc, Sw, Gmi, Sm \\
\hline & Middle shoreface & Sscs, Sc, Hw, Shcs \\
\hline & $\begin{array}{l}\text { Lower shoreface-shelf } \\
\text { transition }\end{array}$ & $\begin{array}{c}\text { Shcs, Hw, Sm, } \\
\text { Sw, Fl, Sl, Sh, Fm }\end{array}$ \\
\hline
\end{tabular}
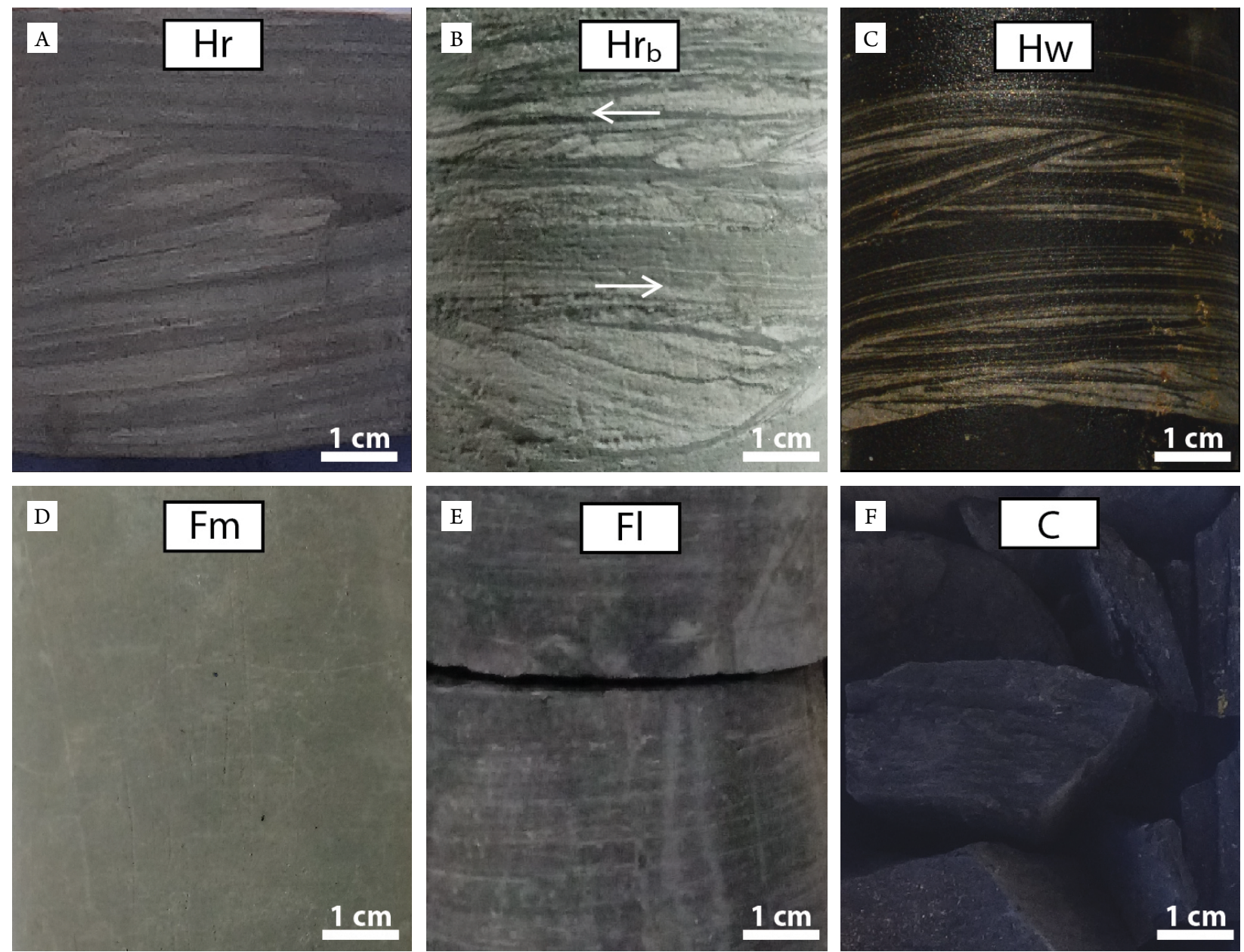

Figure 5. Core photographs of the facies that compose the Rio Bonito Formation in the study area. (A) Heterolithic-wavy, lenticular and flaser bedding - unidirectional ripples cross-lamination in sandy portions ( $\mathrm{Hr}$ ), $124.6 \mathrm{~m}, \mathrm{SG}-02$ well. (B) Heterolithic-wavy, lenticular and flaser bedding - bidirectional (proportion of 1/10) ripples cross-lamination in sandy portions $\left(\mathrm{Hr}_{\mathrm{b}}\right), 147.7 \mathrm{~m}, \mathrm{SG}-03$ well. (C) Heterolithicwavy, lenticular and flaser bedding - wave-ripples cross-lamination in sandy portions (Hw), $89.0 \mathrm{~m}$, SG-03 well. (D) Massive mudstone (Fm), 126.9 m, SG-02 well. (E) Mudstone with parallel lamination (Fl), 107.2 m, SG-02 well. (F) Coal (C), 123.2, SG-02 well. 
plant fragments and diagenetic sideritic (?) nodules are common and millimetric bioturbations (BI: 1-4) are occasional as horizontal excavations in the heterolithic facies.

Interpretation: The bidirectional ripples observed in the heteroliths of the $\mathrm{Hr}_{\mathrm{b}}$ facies are products of a reversal current and of the direction of migration of the sand-sized sediments, which indicates a tidal environment. Areas with high suspensed-sediment concentrations are more likely to have wavy and lenticular beddings (Dalrymple 2010). Tidal flats typically rim the margins of backbarrier lagoons, estuaries
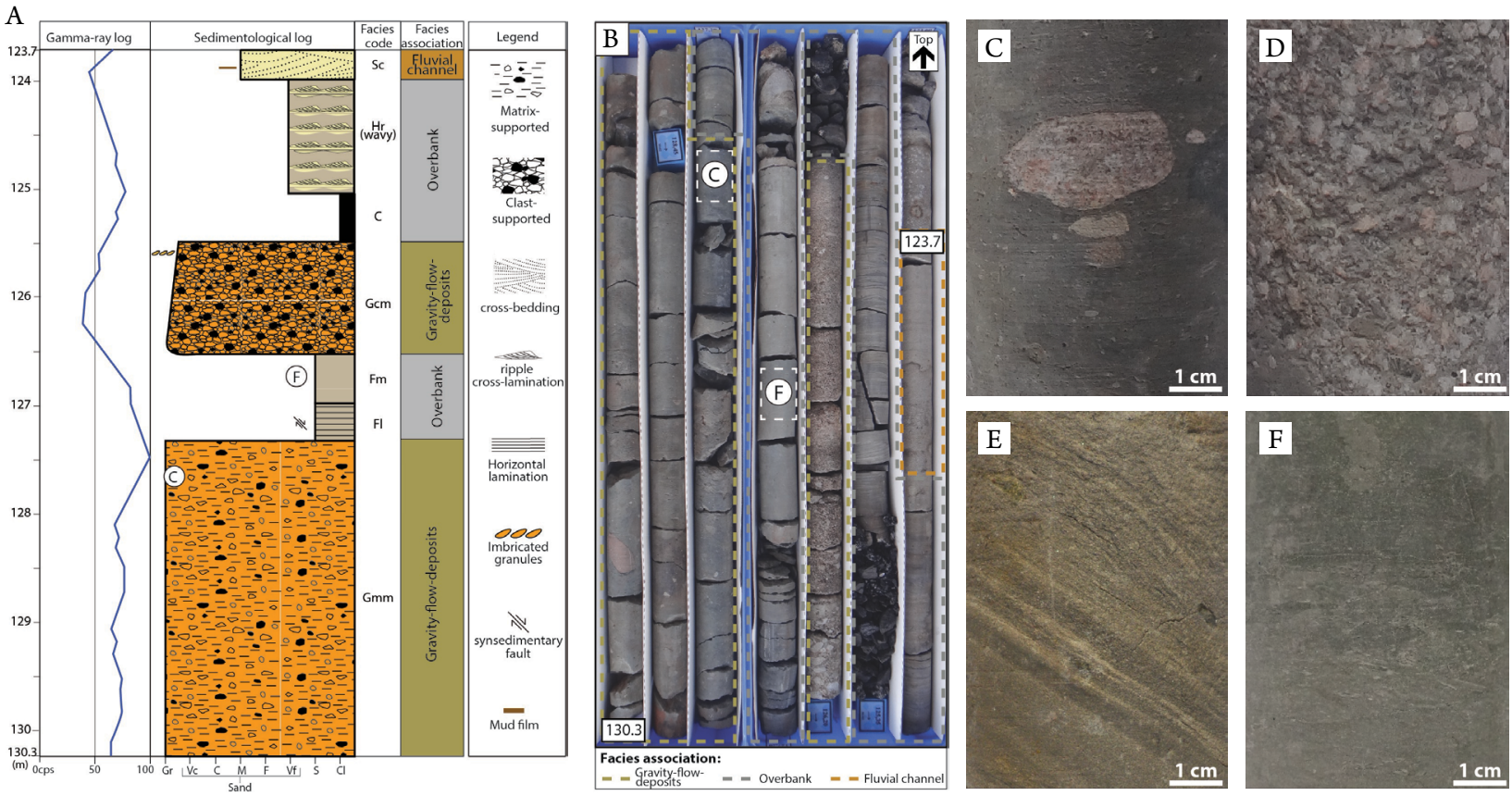

Figure 6. (A) Gamma-ray and sedimentological logs of SG-02 well (123.7 to $130.3 \mathrm{~m})$ showing an example of succession with gravity-flow-deposits, fluvial channel, and overbank facies associations. (B) SG-08 core sample (123.7 to $130.3 \mathrm{~m}$ ). (C) and (D) Core photographs showing massive matrix-supported conglomerate $(\mathrm{Gmm}), 127.6 \mathrm{~m}, \mathrm{SG}-08$ well and clast-supported conglomerate (Gcm), $117.75 \mathrm{~m}, \mathrm{SG}-02$ well, respectivily, both interpreted as gravity-flow-deposits facies association. (E) Core photograph showing fine-grained sandstone with cross-stratification (Sc), $165.6 \mathrm{~m}$, SG-03 well, interpreted as fluvial channel facies association. (F) Core photograph showing massive mudstone (Fm), $126.7 \mathrm{~m}$, SG-02 well, interpreted as overbank facies association.
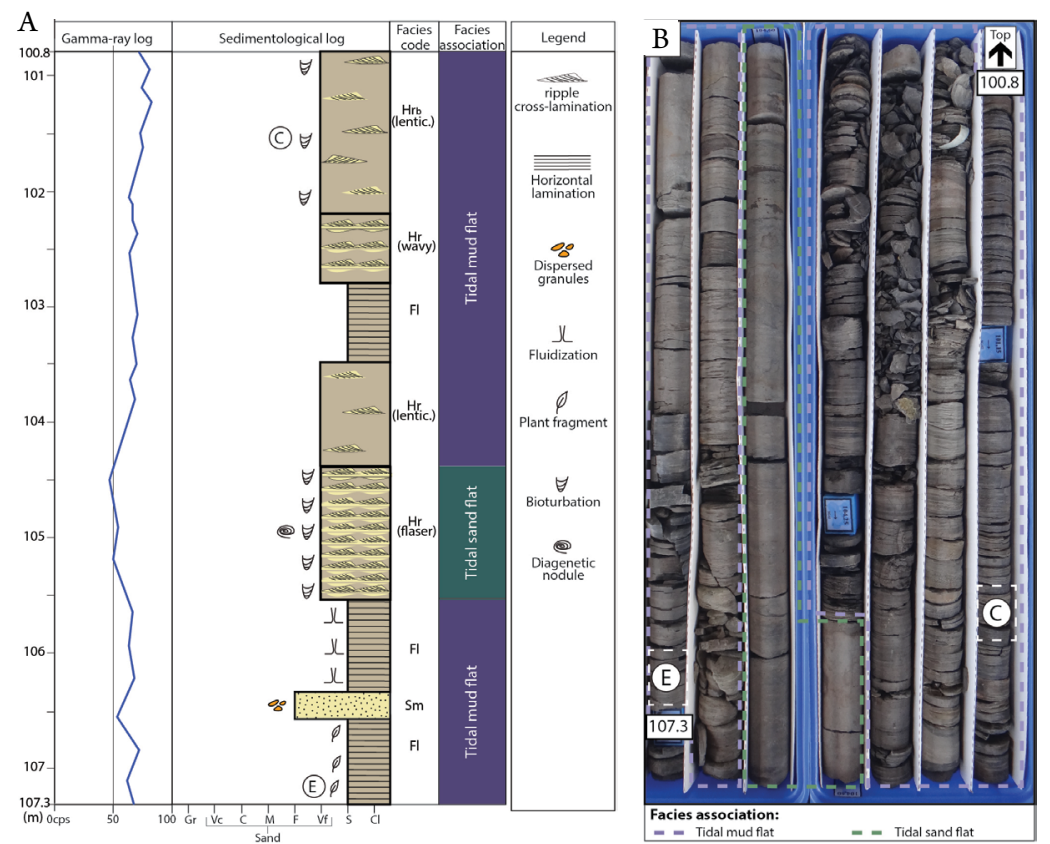
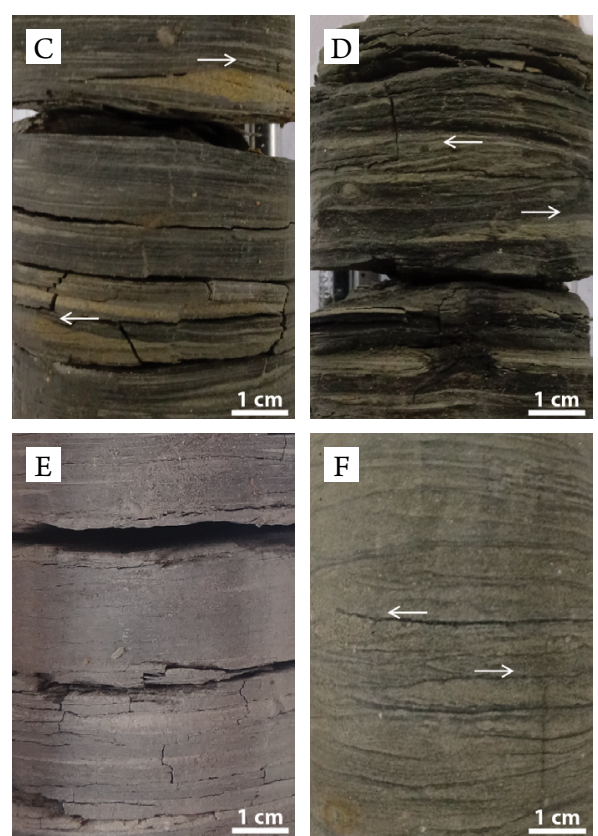

Figure 7. (A) Gamma-ray and Sedimentological logs of SG-02 well (100.8 to $107.3 \mathrm{~m}$ ) showing an example of tidal mud flat and tidal sand flat facies associations. (B) SG-02 core sample (100.8 to $107.3 \mathrm{~m}$ ). (C) and (D) Core photographs showing heteroliths with lenticular-bedded intercalations of very fine sandstones with bidirectional ripples (indicated by the arrows) with mudstones ( $\mathrm{Hr}_{\mathrm{b}}$ ), $101.5 \mathrm{~m}$, SG-02 well and $145.2 \mathrm{~m}$, SG-03 well, respectively. The facies $\mathrm{Hr}_{\mathrm{b}}$ with lenticular-bedding is an indicative of tidal mud flat facies association. (E) Core photograph showing mudstones with parallel lamination (Fl), $107.2 \mathrm{~m}$, SG-02 well, interpreted as tidal mud flat facies association. (F) Core photograph showing heteroliths with flaser-bedded intercalations of very fine sandstones with bidirectional ripples (indicated by the arrows) with mudstones $\left(\mathrm{Hr}_{\mathrm{b}}\right), 115.1 \mathrm{~m}, \mathrm{SG}-02$ well. The facies $\mathrm{Hr}_{\mathrm{b}}$ with flaser-bedding is an indicative of tidal sand flat facies association. 
and open coasts (Dalrymple et al. 1992). Hence, the criteria of Shanmugam et al. (2000) were used to define heteroliths ( $\mathrm{Hr}_{\mathrm{b}}$ and $\mathrm{Hr}$ ), which compose the deposits of tidal mud flats and have wavy or lenticular bedding. In addition to heteroliths, another possible facies is $\mathrm{Fl}$, in which sand is absent indicating a dominant muddy environment without current periods.

\section{Tidal sand flat facies association}

Description: This facies association represents $4 \%$ of the stratigraphic record (Suppl. A1). It occurs in SG-02, SG-03, SG-04 and SG-08 wells, with thicknesses varying from 0.65 to $4.2 \mathrm{~m}$. The facies components of this association are heterolithic intercalations - flaser or wavy bedding — with bidirectional $\left(\mathrm{Hr}_{\mathrm{b}}\right)$ or unidirectional $(\mathrm{Hr})$ ripples cross-lamination in sandy portions, massive sandstones, or with unidirectional ripples (locally bidirectional) ( $\mathrm{Sr}$ ), unidirectional (locally bidirectional) ripples and mud drapes $\left(\mathrm{Sr}_{\mathrm{d}}\right)$, sandstones with horizontal to low-angle cross-stratification (Sh), or rarely, cross-stratified (Sc) (Figs. 7A, 7B and 7F; Tab. 3; Suppl. A2). Plant fragments (Fig. 8), dispersed granules and pebbles of quartz and lithic fragments occur occasionally. In addition, horizontal millimetric bioturbations (BI: 3) are locally present.

Interpretation: Following the same criteria used in the mud flat facies association, tidal sand flat deposits (Dalrymple et al. 1992) were identified by the bidirectionality found in the $\mathrm{Hr}_{b}$, $\mathrm{Sr}$ and $\mathrm{Sr}_{\mathrm{d}}$ facies. Additionally, flaser bedding is also more likely to occur in areas with stronger currents because these currents can erode freshly deposited mud from the ripple crests (Dalrymple 2010). Areas with low suspensed-sediment concentrations will more often produce flaser bedding (Dalrymple 2010). So, according to Shanmugam et al. (2000), the heteroliths of this facies association only have flaser bedding ( $\mathrm{Hr}_{\mathrm{b}}$ and $\mathrm{Hr}$ facies). The other facies that compose this association contains little or no mud, indicating an environment with frequent fast currents and dominance of sandy sediments.

\section{Tidal sand bar facies association}

Description: This facies association represents $19 \%$ of the stratigraphic record (Suppl. A1). It has large thicknesses of 11.3 m (SG-02 well), 18.3 m (SG-03 well), 12.09 m (SG-04 well), and $29.37 \mathrm{~m}$ (SG-08 well). This association comprises mainly sandstones with cross-stratification and mud drapes $\left(\mathrm{Sc}_{\mathrm{d}}\right)$, with cross-stratification $(\mathrm{Sc})$ or with ripples cross-lamination and mud drapes $\left(\mathrm{Sr}_{\mathrm{d}}\right)$ (Fig. 9; Tab. 3; Suppl.A2). Subordinately, other facies may occur, such as massive sandstones $(\mathrm{Sm})$, with ripples cross-lamination (Sr) or with horizontal to low-angle stratification (Sh), heteroliths with unidirectional ripples cross-lamination in sandy portions $(\mathrm{Hr})$ and mudstones with parallel lamination $(\mathrm{Fl})$. In general the sandstones of this facies association are well to moderately-sorted, rarely poorly-sorted, fining-upward trending and usually present cross-stratification with millimetric single (rarely double) mud drapes or millimetric muddy layers intersets. Erosion records locally occur between the tidal bars, including mud intraclasts and millimetric plant fragments. Also, millimetric to centimetric bioturbation (BI: 1-3), as horizontal excavations, occur occasionally. This facies association occurs interspersed with deposits of intertidal mud and sand flats, or even with shoreface deposits.

Interpretation: Typical facies of this association are $\mathrm{Sc}_{\mathrm{d}}$ and $\mathrm{Sr}_{\mathrm{d}}$, which have their bed forms linked to the high-energy alternation in a subaqueous environment with dunes $\left(\mathrm{Sc}_{\mathrm{d}}\right)$ or ripples $\left(\mathrm{Sr}_{\mathrm{d}}\right)$ migration under a low flow regime for the sands and absence of energy to the deposition of mud. The preservation of delicate mud drapes indicates a protected environment, such as an estuary (Shanmugam et al.2000). Tidal bars and tidal dunes are sandy facies associations characteristic of estuarine depositional systems; However, following Olariu et al. (2012), the first is parallel and the second perpendicular to the depositional dip, but both similar in their overall facies. But, according to the same authors, one of the criteria to differentiate one from the other in ancient deposits is the vertical grain size trend, because tidal dunes tend to have a coarsening-upward trend, whereas tidal bars usually have a finning-upward
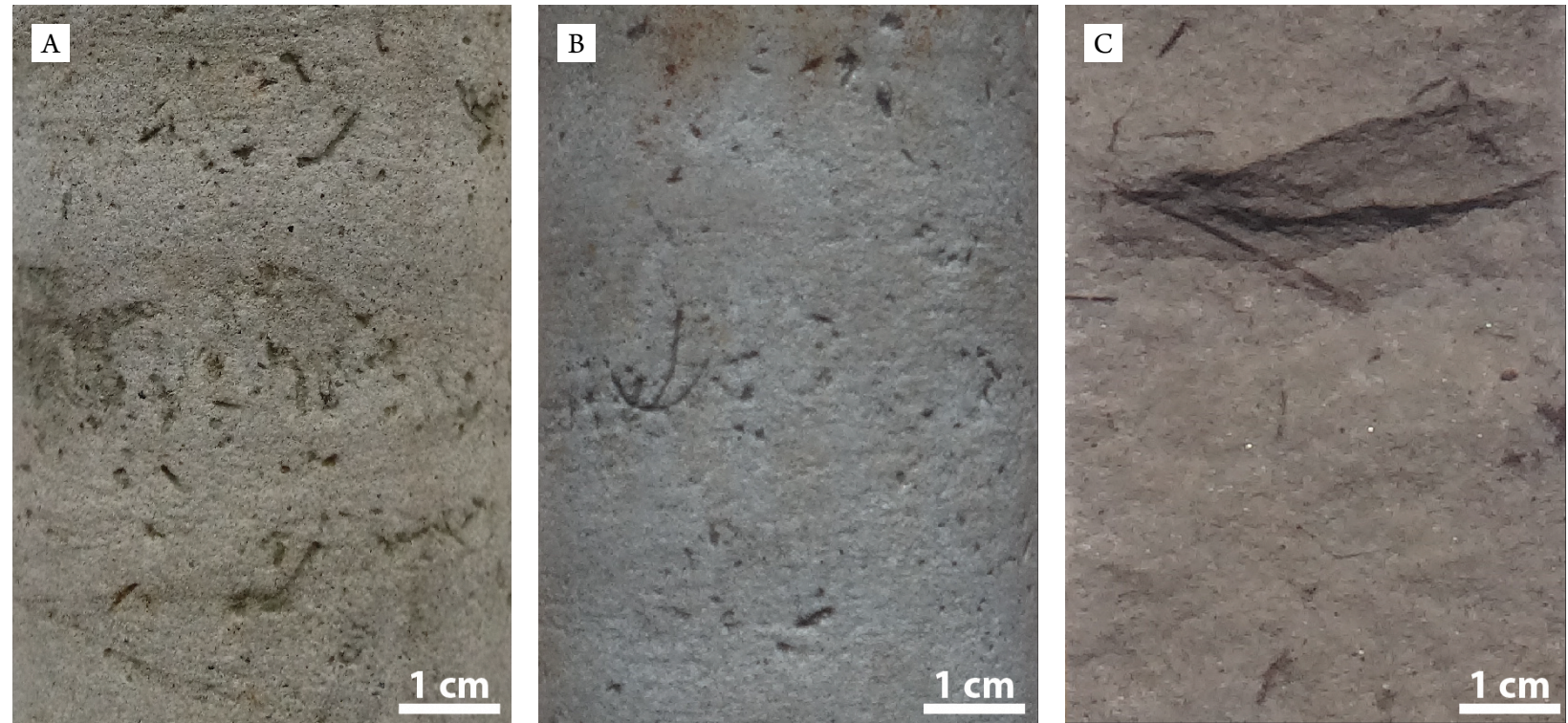

Figure 8. Core photographs showing plant fragments in tidal sand flat facies association. (A) and (B) 78.6 and 78.4 m, respectivity, SG-03 well. (C) $89.8 \mathrm{~m}$, SG-02 well. 
pattern. Since the layers found are often fining-upward (Fig. 9A; Tab. 2, facies $S_{c_{d}}$ ), these deposits were interpreted as tidal bars.

\section{Upper shoreface facies association}

Description: This facies association represents $7.5 \%$ of the stratigraphic record (Suppl. A1). Its thicknesses vary from a few centimeters up to $7.75 \mathrm{~m}$ and it comprises mainly fine to medium-grained sandstones with horizontal to low-angle cross-stratification (Sh), coarse to medium-grained sandstones with cross-stratification $(\mathrm{Sc})$ and fine-grained sandstones with wave-ripples cross-lamination $(\mathrm{Sw})$ (Figs. 10A, 10B and 10C; Tab. 3; Suppl. A2). Other relevant facies is massive or
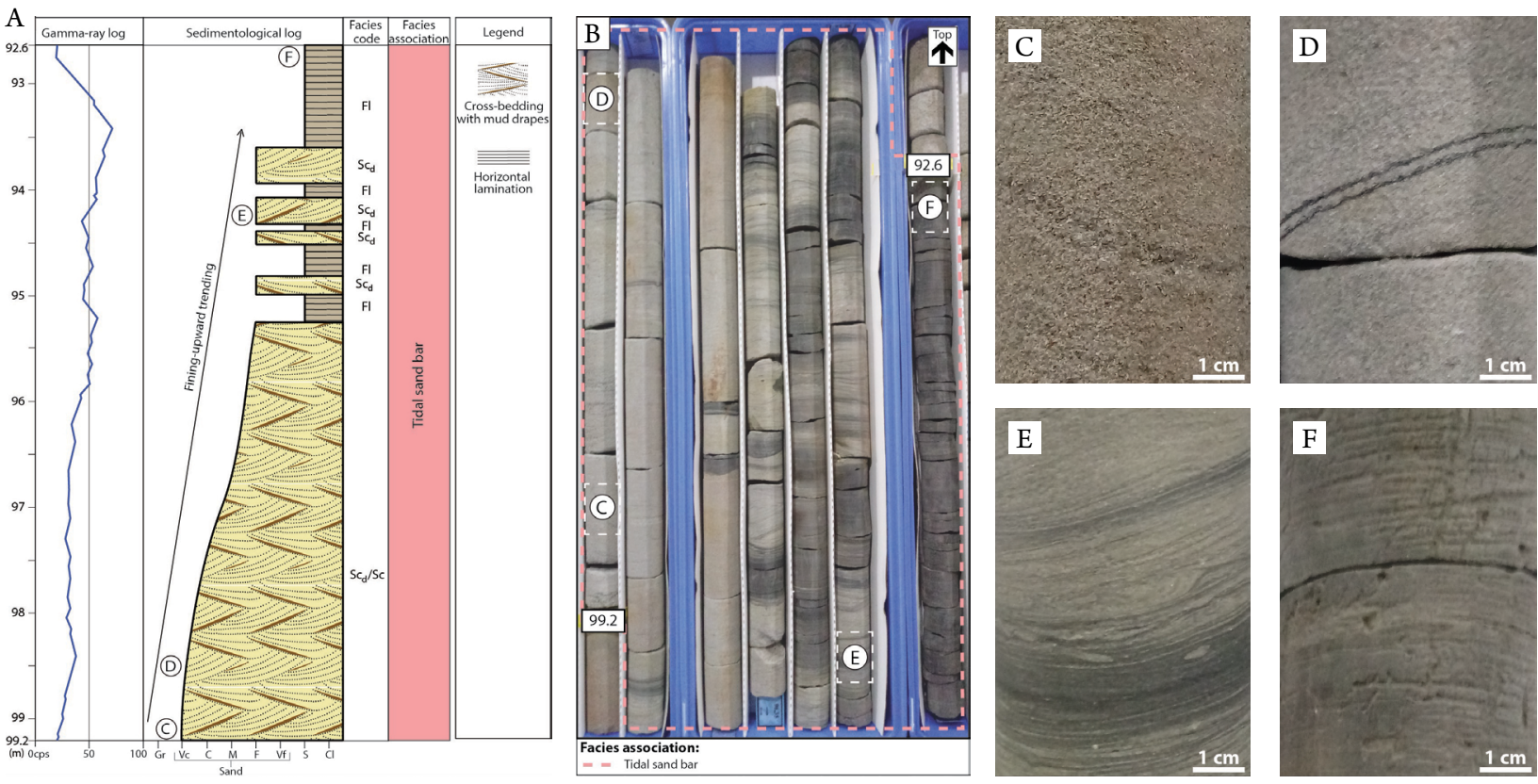

Figure 9. (A) Gamma-ray and sedimentological logs of SG-08 well (92.6 to $99.2 \mathrm{~m}$ ) showing an example of tidal sand bar facies association with fining-upward trending (note the arrow). (B) SG-08 core sample (92.6 to $99.2 \mathrm{~m}$ ). (C) Core photograph showing very-coarse-grained sandstone with cross-stratification (Sc), $99.1 \mathrm{~m}, \mathrm{SG}-08$ well. (D) Core photograph showing coarse-grained sandstone with cross-stratification and mud drapes (Scd), $98.5 \mathrm{~m}$, SG-08 well. (E) Core photograph showing fine-grained sandstone with cross-stratification and mud drapes (Scd), 94.3 m, SG-08 well. (F) Core photograph showing mudstone with parallel lamination (Fl), $92.55 \mathrm{~m}$, SG-08 well.
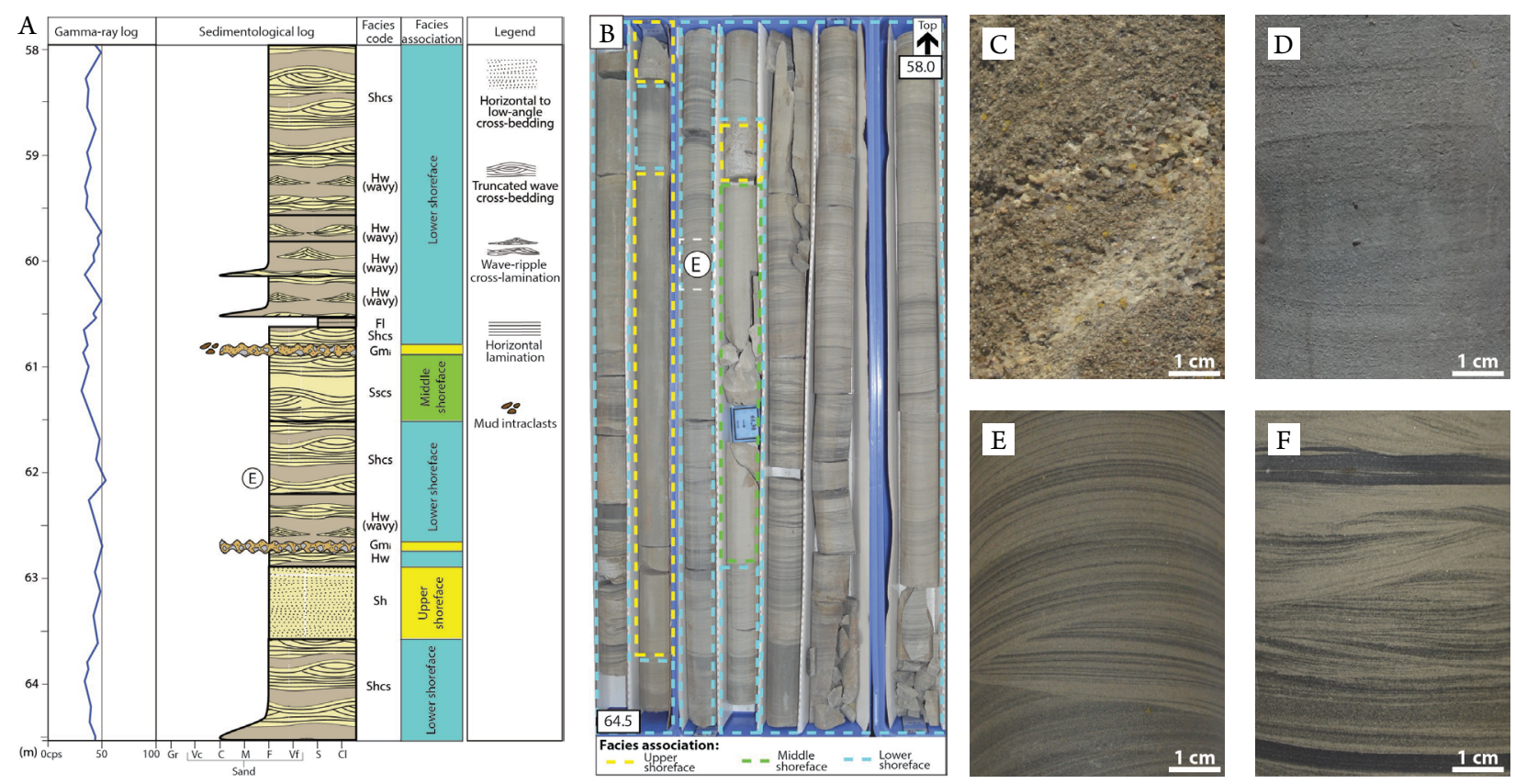

Figure 10. (A) Gamma-ray and sedimentological logs of SG-08 well ( 56.15 to $62.7 \mathrm{~m}$ ) showing an example of upper, middle and lower shorefaces facies associations. (B) SG-08 core sample (56.15 to $62.7 \mathrm{~m}$ ). (C) Core photographs showing medium-grained sandstone with cross-stratification (Sc), $324.9 \mathrm{~m}$, SG-17 well, interpreted as upper shoreface facies association. (D) Core photographs showing mediumgrained sandstone with swaley cross-stratification (Sscs), $48.0 \mathrm{~m}, \mathrm{SG}-08$ well, interpreted as middle shoreface facies association. (E) Core photographs showing fine-grained sandstone with hummocky cross-stratification (Shcs), $62.1 \mathrm{~m}, \mathrm{SG}-08$ well, and heteroliths with wavy-bedded intercalations of fine-grained sandstones with wave-ripples with mudstones ( $\mathrm{Hw}), 73.0 \mathrm{~m}, \mathrm{SG}-08$ well, respectivity, both interpreted as lower shoreface-shelf transition facies association. 
faint bedded coarse-grained sandstones to clast-supported conglomerates with immature composition $\left(\mathrm{Gm}_{\mathrm{i}}\right)$ which has erosive top and basal contacts (Fig. 4C). Subordinately, fine to coarse-grained massive sandstones $(\mathrm{Sm})$ are also present. Upper shoreface deposits occur in occasional normal grading, but usually it happens interbedded with those of middle and lower shorefaces, commonly with gradual contacts. In this facies association some thin mud films occur locally and mud intraclasts and unidiretional ripples marks are rare. The exception is the $\mathrm{Gm}_{\mathrm{i}}$ facies, which has coarser grain-sizes and top and base erosive contacts.

Interpretation: According to Plint (2010), an upper shoreface is formed by a breaking zone, ridge-and-runnel/rip channels and its main structure is crossbedded sandstone. Thus, the upper shoreface facies association represents an environment of continuous interaction between the waves and the seabed in a zone closer to coastline, above the fairweather wave base. The main facies of this association is horizontal to low-angle cross-stratification sandstones (Sh), which in this context is interpreted as formed by a combined-flow of oscillatory and unidirectional current components (Duke et al. 1991). On the other hand, sandstones with cross-stratification (Sc) represent, according to Plint (2010), migration of dunes in shoreface where longshore bars are developed. Facies $\mathrm{Gm}_{\mathrm{i}}$ is a lag deposit related to the process of sediments reworking, such as coarse-grained sand, granules and pebbles with some lithification, and it was interpreted as a bedset boundary or a wave-ravinement surface, according to Zecchin et al. (2017).

\section{Middle shoreface facies association}

Description: This facies association represents $4.5 \%$ of the stratigraphic record (Suppl. A1). Its thickness varies from $40 \mathrm{~cm}$ to $7.4 \mathrm{~m}$. These deposits are constituted dominantly by medium to fine-grained sandstones with swaley cross-stratification (Sscs) (Figs. 10A, 10B and 10D; Tab. 3; Suppl. A2). Other facies that also occur in lower proportions are coarse to medium-grained sandstones with cross-stratification $(\mathrm{Sc})$, hummocky cross-stratification (Shcs), and heteroliths with wave-ripples cross-lamination $(\mathrm{Hw})$ in sandy portions.

Interpretation: According to Plint (2010), mud-free swaley cross-stratification deposits represent the middle shoreface. This association is situated in the shoreface intermediate portion, in a stratigraphic position above the Hcs and below the beach deposits. According to Duke (1985) and Dumas and Arnott (2006), swaley cross-stratification is formed by stormwaves in an oscillatory-dominant high-energy combined-flow regime. The preponderance of erosional swales over constructional hummocks is attributed to deposition in shallower water where aggradation rate is lower and scouring is more frequent (Plint 2010).

\section{Lower shoreface-shelf transition facies association}

Description: This facies association represents $46 \%$ of the stratigraphic record (Suppl. A1). Its thicknesses vary from $15 \mathrm{~cm}$ up to $18.3 \mathrm{~m}$, and it is primarily composed by fine-grained sandstones with hummocky cross-stratification (Shcs) and heteroliths with wave-ripples cross-lamination $(\mathrm{Hw})$ in sandy portions (Figs. 10A, 10B, 10E and 10F; Tab. 3; Suppl. A2). Both, Shcs and $\mathrm{Hw}$ facies, are very commonly bioturbated. In Shcs, bioturbations (BI: 1-6) are present as centimetric to millimetric horizontal and vertical excavations, and in $\mathrm{Hw}$, those marks are millimetric horizontal escavation (BI: 3-4). Subordinately, fine to coarse-grained massive sandstones (Sm) or with wave-ripples cross-lamination $(\mathrm{Sw})$ and laminated mudstones ( $\mathrm{Fl}$ ) are also present. Other facies rarely occur, such as sandstones with horizontal to low-angle cross-stratification (Sh) and massive mudstones (Fm). Other characteristics as fluidization marks occur locally and mud intraclasts and diagenetic sideritic (?) nodules are rare.

Interpretation: According to Plint (2010), hummocky cross-stratification and muddy and highly bioturbated shelf deposits represent the lower shoreface-shelf transition. It is related to more distal portions of a shallow-marine environment, where there is low or absence of energy and, consequently, decantation of suspended sediments predominates and the wave interaction with the seabed occurs only in storm events. Shcs and $\mathrm{Hw}$ are the main facies of this association. Shcs has its structure originated in a regime of dominant oscillatory currents due to the action of strong waves during storm events (Dumas \& Arnott 2006). Such deposits are formed below the fairweather wave base and, according to Dumas and Arnott (2006), just above the storm wave base, where aggradation rates during storms are high enough to preserve hummocks. On the other hand, facies $\mathrm{Hw}$ represents an alternation between wave activity and decantation. In this way, mudstones were deposited by suspension and decantation of grains below the fairweather wave base (McCormick \& Grotzinger 1993) close to the storm wave base, and the sand portions with wave-ripples cross-lamination, which record storm events, were deposited in a context of oscillatory flow.

\section{Depositional systems}

\section{Fluvial depositional system}

The fluvial depositional system is related to the most proximal portion among the identified systems. This depositional system is composed by gravity-flow-deposits, fluvial channels and overbank facies associations, occurring mostly at the bottom of the described cores. Although fluvial style was not defined, a considerable amount of overbank deposits, composed of flood-plains, levees and crevasse splay deposits, allows the interpretation of a very wet environment with frequent floods, like meandering and anastomosing rivers. Furthermore, this system has several gravity-flow-deposits interleaved mainly with overbank ones, implying that this fluvial environment was bounded by high areas of the Precambrian basement, which contributed to the fluvial discharge in the beginning of the Rio Bonito Formation deposition.

\section{Tide-dominated estuary depositional system}

The tide-dominated estuary depositional system is composed of tidal mud flat, tidal sand flat and tidal sand bar facies associations and occurs mainly at the bottom and central 
portions of the described cores. This tide-dominated estuary system was developed in a macrotidal coast, which favored the development of tidal sand bars and tidal sand flat in the central axis of the estuary, surrounded by tidal mud flat and supratidal (inferred). The main diagnostic features of an estuarine environment are represented by deposits with mud drapes (tidal sand bars), that indicate periodic fluctuations of the environment energy and by bidirectional tractive structures (tidal flats), that indicate current reversion.

\section{Wave-dominated shallow-marine system}

The three facies associations that make up this depositional system occur in all core samples described, mainly in the central and top portions or in the whole core sample (SG-17 well). In general, the boundaries between shorefaces facies associations are not completely clear, especially between the middle shoreface and lower shoreface-shelf transition, due to the transitions between the wave energy active zones/depths. In this depositional setting, sedimentary structures such as wave-ripples cross-laminations formed by fairweather waves, hummocky and swaley cross-stratifications associated to storm events commonly occur, which indicate a wave-dominated shallow-marine depositional system with frequent storm events.

\section{Depositional model and paleoenvironmental evolution}

Gathering all the facies associations and depositional systems, a depositional model was proposed for the Rio Bonito Formation, in São Gabriel City, with a depocenter to northeast (Reis 2007). The simplified depositional model is composed of a proximal fluvial system transitioning for a tide-dominated estuarine environment and a distal wave dominated shallow system. The three distinct paleoenvironmental stages for Rio Bonito Formation in the region of São Gabriel are represented in Figure 11.

Paleoenvironmental stages represent dominantly fluvial (S1), tide-dominated estuary (S2) and wave-dominated shallow-marine (S3) depositional systems. All the cores encompass well preserved records of the three paleoenvironmental stages, with exception of SG-17 well, which has only shallow-marine deposits of S3.

In $S 1$, the fluvial depositional system was dominant, deposited over the crystalline Precambrian basement. At this stage, gravity-flow-deposits were proximal and fluvial channels with overbank deposits covered most of the area.

S1 was followed by dominant tide-dominated estuarine deposits (S2). During S2, tidal facies were deposited over the fluvial deposits (S1). At this stage, some final fluvial deposition occurred in proximal areas concomitantly to the distal deposition of shallow-marine deposits.

The last stage is represented by a wave-dominated shallow-marine system (S3) with the development of foreshore (inferred) and upper, middle and lower shorefaces at higher depths. At this time, shallow-marine facies were deposited over the estuarine deposits (S2). Furthermore, some final estuarine deposition occurred proximally as a closed estuary in a wave-dominated shoreline with minor tidal contribution.
Although depositional systems are dominant at some stages, several interdigitations occurred between them, evidencing that shorelines regression and advances changed the environmental conditions, according to the proposed stratigraphic framework.

\section{Statigraphic framework}

A stratigraphic framework with key stratigraphic surfaces and system tracts was stablished through a strike-oriented (SE-NW) correlation section (Fig. 12), using a proximal (SG-08) and four distal wells (SG-02, SG-03, SG-03 and SG-17), recording the evolution of the depositional environments and relative sea-level and accommodation fluctuations.

In total, eight stratigraphic surfaces were defined: two subaerial unconformities (SU), three maximum regressive surfaces (MRS), three maximum flooding surfaces (MFS) and a wave-ravinement surface (WRS). According to Milani (2000), after a long series of transgressive trends in relative sea-level fluctuations, a second order MFS records maximum regional flooding of Gondwana Supersequence I in the early Permian. Therefore, this MFS is a datum for the studied interval, named as MFS-3 in this work and defined in wells using the highest gamma-ray value at the top of the Rio Bonito Formation or within the Palermo Formation.

\section{Stratigraphic surfaces}

SU-1 occurs at the base of all boreholes, where the sedimentary succession begins directly over the crystalline Precambrian basement. This surface represents erosion or a depositional hiatus in the sedimentary register.

MRS- 1 was distally positioned by the first estuarine influence in each borehole (e.g., bidirectional tractive structures). Following the depositional model proposed, gravity-flows-deposits occurred in proximal areas while fluvial channel and overbank facies associations occurred in distal portions. Proximally, MRS-1 was inferred to occur at the top of gravity-flow-deposits (note the dashed line and question mark in Fig. 12).

MFS-1 was identified only in the SG-04 well, within shallow-marine beds which overlie estuarine deposits. At this point, a deepening upward trend changes to shallowing upward (gradationally based). In the other wells, this surface was inferred (note the dashed line and question mark in Fig. 12).

SU-2 and MRS-2 were inferred (note the dashed line and question mark in Fig. 12) as condensed surfaces between two evident deepening upward trends (except for SG-04 that has a shallowing upward succession between the two deepening upward cycles). In the distal portion, these surfaces are evidenced by tidal sand bars directly (sharp based) over shallow-marine deposits, and by upper shoreface directly (sharp based) over lower shoreface-shelf transition deposits. Direct occurrence of estuarine over shallow-marine deposits suggests forced regression followed by a normal regressive event, since strata over the sharp based contact is also deepening upward. Thus, in the proximal portion, those surfaces were also inferred to be within tidal sand bars based on the spatial distribution of the deposits in the model proposed, as distal shallow-marine and proximal estuarine deposits occur 
before SU-2 and MRS-2. After the SU-2, both distal and proximal portions are estuarine.

MFS-2 was positioned at the end of the second deepening upward succession within the lower shoreface-shelf transition beds in all boreholes, especially where heteroliths with wave-ripples cross-laminations are dominant. The highest gamma-ray value was the main criteria for positioning this surface at this point, marking the end of a transgressive event. MRS-3 was established at the end of a shallowing upward pattern constituted by the normal regression of shallow-marine facies. This surface occurs at the top of the upper shoreface beds at distal and proximal portions. SG-04 well has no core
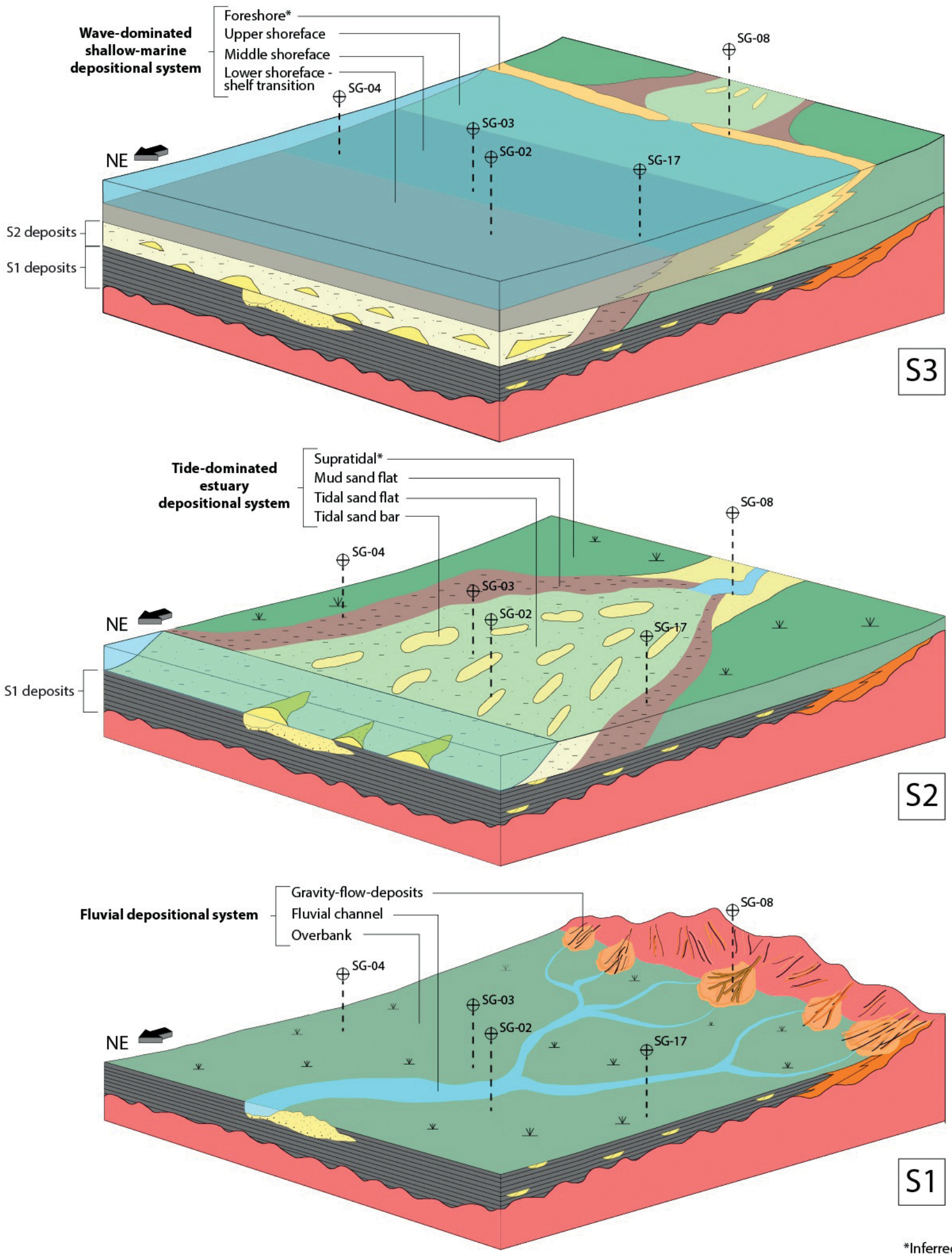

Figure 11. Schematic depositional model and correspondent paleoenvironmental evolution in three stages — S1, S2 and S3 - from bottom (older) to top (younger), of the Rio Bonito Formation in São Gabriel City. 
descriptions, so MRS-3 was defined by the lowest gamma-ray value (note the dashed line and question mark in Fig. 12).

Finally, MFS-3 occurs at the end of the last deepening upward trend and was defined by the highest gamma-ray value within shallow-marine deposits. This surface marks the maximum transgressive event in the studied interval.

\section{System tracts}

Lowstand system tract 1 (LST-1) was deposited directly over the crystalline Precambrian basement. Its boundary surfaces are SU-1 (base) and MRS-1 (top), and its thickness varies from 2 to up to $19.7 \mathrm{~m}$ (with the exception of SG-17 well, where it does not occur). This first normal regression is composed of fluvial deposits, mainly fluvial channel and overbank facies associations in the distal portion and gravity-flow-deposits facies association in the proximal portion. There is no estuarine or shallow-marine evidence or intercalation.

Transgressive system tract 1 (TST-1) is limited at the base by MRS- 1 and at the top by SU- 2 and its thickness varies from 4.5 to $41 \mathrm{~m}$. Evident retrogradation occurs in the distal portion with the overlapping of shorefaces deposits, and an estuarine system (tidal sand bar facies association) occurring proximally. TST-1 matches the first trangressive event.

The only record of the highstand system tract 1 (HST-1) is in SG-04 well. It presents a thickness of $7.6 \mathrm{~m}$ and is limited at the base by MFS- 1 and at the top by SU- 2 and MRS-2 surfaces. This short interval is the whole lower shoreface-shelf transition facies association, although it begins with heterolithic intercalations with wave-ripples cross-lamination and varies to sandstones with hummocky cross-stratification at the top. HST-1 corresponds to the second normal regression.
As explained before, two condensed surfaces - SU-2 and MRS-2 - and two regressive events - forced and normal - were inferred between two deepening upward trends. Thus, the first (and sole) forced regressive event represents the falling stage system tract 1 (FSST-1) and the third normal regressive event matches the lowstand system tract 2 (LST-2).

Transgressive system tract 2 (TST-2) is limited at the base by MRS- 2 and at the top by MFS-2. Its thickness varies from 17.7 to $42.3 \mathrm{~m}$. This system tract is generally recorded at the base by tidal sand bars (SG-02, SG-03, SG-04 and SG-08 wells) and upper shoreface (SG-17 well), followed by upper and lower shoreface-shelf transition facies associations. SG-04 well $(45.9 \mathrm{~m})$ presents a 15 -cm-thick layer of $\mathrm{Gm}_{\mathrm{i}}$ facies (lag deposits), which records the contact between tidal sand bars (base) and middle shoreface deposits (top) and represents a wave-ravinement surface (WRS). TST-2 corresponds to the second transgressive event.

Highstand system tract 2 (HST-2) is limited by MFS-2 (base) and MRS-3 (top) surfaces, and its thickness varies from 9.6 to $31.5 \mathrm{~m}$. This interval is mainly composed of wave-dominated shallow-marine deposits, with dominance of lower shoreface-shelf transition in the basal portion, prograding to middle and upper shorefaces towards the top. HTS-2 represents the fourth normal regressive succession.

Transgressive system tract 3 (TST-3) is limited in the lower portion by MRS-3 and by MFS-3 (datum) in the upper portion, and its thickness varies from 1.4 to $25.1 \mathrm{~m}$. As HST-2, this system tract (TST-3) is composed only of shallow-marine deposits, but with a retrogradational trend. TST-3 corresponds to the third transgressive event.

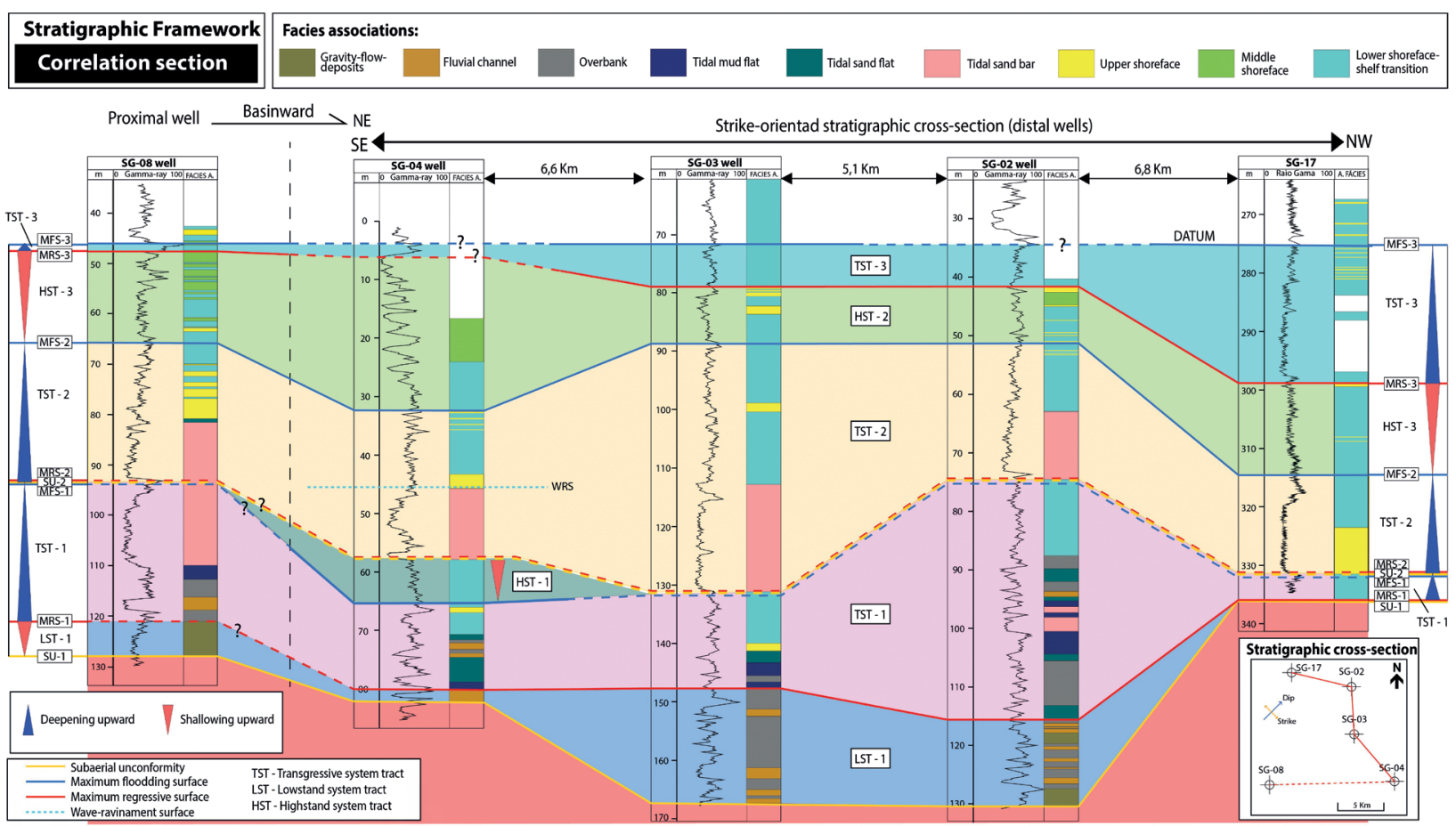

Figure 12. Correlation section of the facies association interpreted in SG-08 (proximal), SG-02, SG-03, SG-04 and SG-17 (distal) wells, showing the key stratigraphic surfaces (dashed lines and question marks represent inference) and system tracts. Note the datum concurs with maximum flooding surface-3 (MFS-3) at the top succession, upward trendings and lateral thickness variations in system tracts of the Rio Bonito Formation in São Gabriel City. 


\section{Curve of accommodation changes}

Through the correlation section, a dip-oriented stratigraphic profile with correspondent lithostratigraphic limits (Fig. 13) and a curve of accommodation changes were created for the studied interval in São Gabriel (Fig. 14). LST-1 represents the first deposits in a context of low accommodation rates in relation to sediment supply $(\mathrm{A}<\mathrm{S})$. Then, TST-1 registers an increase in the accommodation rates $(\mathrm{A}>>\mathrm{S})$ and HST-1 a new decrease in the accommodation rates $(\mathrm{A}<\mathrm{S})$. HST-1 was partially eroded, represented only in the SG-04 well. FSST-1 was interpreted as representing a base level fall and destruction of accommodation $(\mathrm{A}<<\mathrm{S})$. Thus, FSST-1 probably eroded most of HST-1 and part of TST-1. Before TST-2 deposition, LST-2 was developed by an accelerating rate of accommodation $(\mathrm{A}<\mathrm{S})$, and was probably eroded or not deposited. TST-2 shows an increase in the rates of accommodation in relation to sediment supply (A >>S). Then, HST-2 represents a decrease in the accommodation rates $(\mathrm{A}<\mathrm{S})$ without base level fall. TST-3 upper portion represents the maximum accommodation of the studied succession. In addition, some portions of TST-2, HST-2 and mainly of TST-3 can be equivalent to the Palermo Formation (Fig. 13).

\section{DISCUSSION}

Reis (2007) proposed a mixed estuarine depositional system for the Rio Bonito Formation, in São Gabriel City, through the study of seven boreholes (SG-02, SG-03, SG-05, SG-07, SG-08, SG-13, and SG-14), with four sub environments: bayhead-delta, central basin, intertidal and tidal-channel, and small barrier bar deposits (composed by massive coarse-grained sandstones - Sm facies - , with thick beds of up to $1 \mathrm{~m}$ ) making up a wave-dominated shallow-marine depositional system. The previous interpretation of barrier facies association of Reis (2007) is contested in this work, relating Sm facies to upper shoreface facies association. However, a shift on the interpretation of a barrier to an upper shoreface is not so far, due to the proximity of these subsystems. According to Dalrymple et al. (1992), both wave- and mixed- (wave and tidal) dominated estuaries have a barrier system, well- and partially- developed, respectively. On the other hand, in tide-dominated estuaries, tidal energy increases in relation to wave energy and the barrier system of wave-dominated estuaries becomes progressively more dissected by tidal inlets and elongate sand bars develop in place of barrier segments and channel-margin linear bars of ebb-tidal deltas (Dalrymple et al. 1992). Thus, the absence of barrier bars and dominance of tidal sand bars deposits over fine-grained tidally-influenced facies described, mainly in the TST-2 (Fig. 12), indicate an open estuary, where oscillatory processes were subordinate preventing the development of a lagoonal estuarine system. Furthermore, muddy sediments

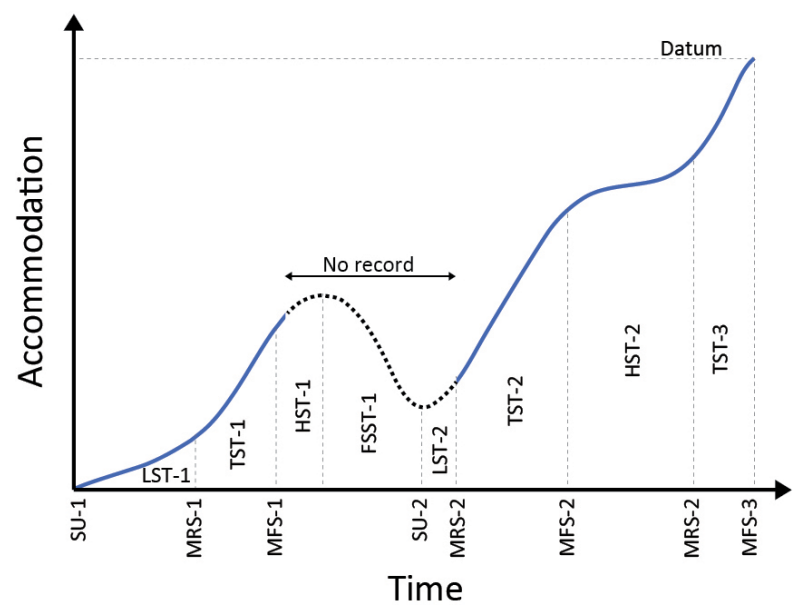

Figure 14. Curve of accommodation changes along time with indication of the system tracts and key stratigraphic surfaces interpreted. The dashed line indicates absence of rock records (inferred events).

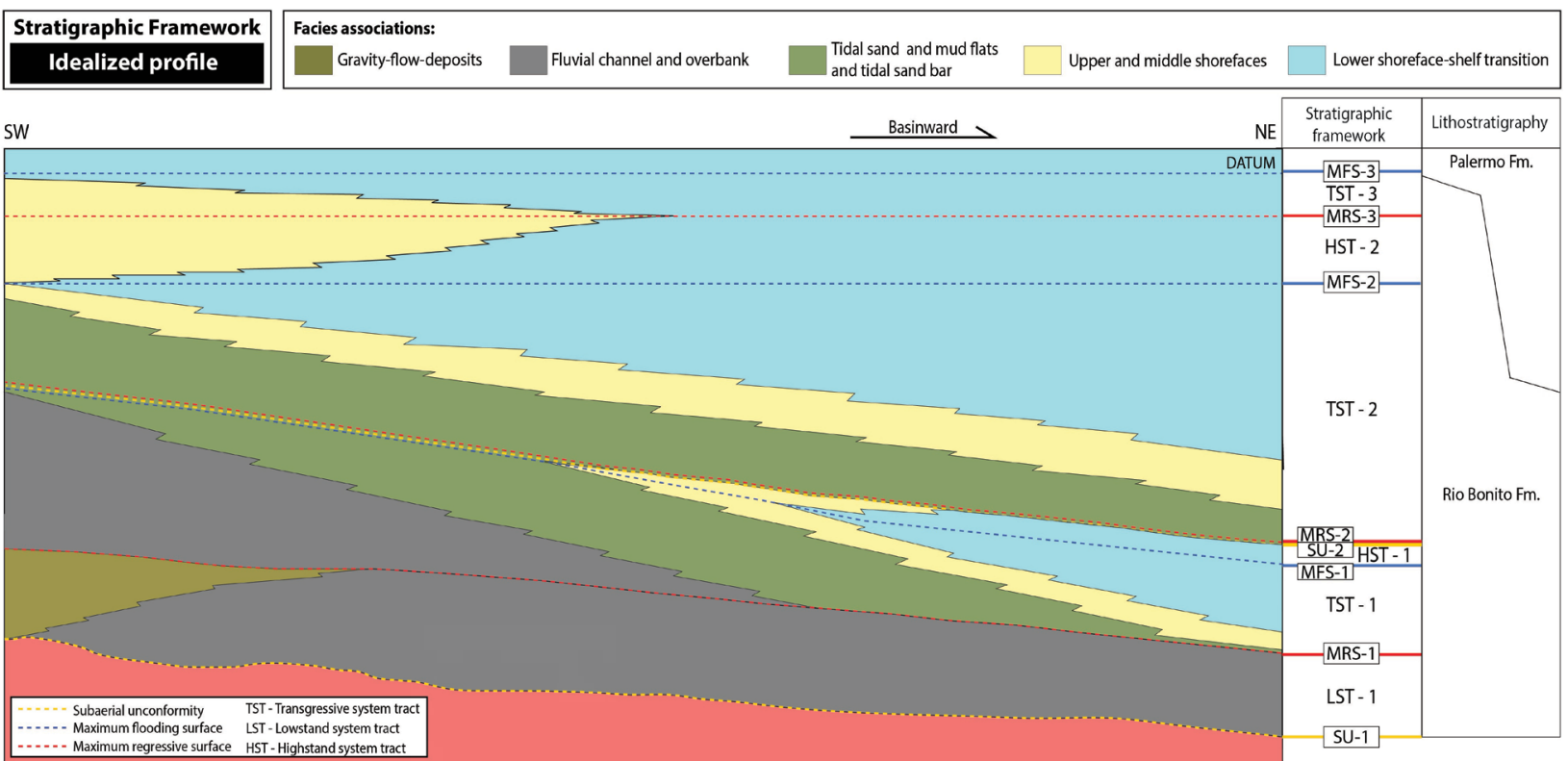

Figure 13. Dip-oriented cross section through an idealized profile of the overview stratigraphic framework and lithostratigraphic unit equivalents of the studied interval, in the city of São Gabriel. 
accumulate primarily in tidal flats and marshes along the sides of the tide-dominated estuarine systems (Dalrymple et al. 1992). Then, the interpretation of tidal mud and sand flats is supported by the presence of heterolithic intercalations with bidirectional tractive structures (ripple cross-lamination) and sandstones with plant fragments (Fig. 8). Besides that, according to Harris (1988), the filling of an estuary produces a bedform evolutionary sequence, with an initial muddy stage (mud tidal flats onshore and coarse sands bars offshore) and a final stage with onshore sand bars. This evolutionary sequence was identified in the study area, since TST-1 (first stage) presents tidal flats and some tidal sand bars and TST-2 (final stage) presents mostly tidal bars (Fig. 12).

As described by Dalrymple et al. (1992), estuarine systems are formed only in transgressive contexts (relative sea-level rises), in which incised valleys are inherited from previous stages of base-level fall and are not entirely filled by lowstand deposits. Their distal portions are commonly converted into estuaries at the onset of a transgressive event (Dalrymple et al. 1994). Throughout the sedimentary successions preserved in some paleovalleys along the eastern border of the Paraná Basin (Candiota, Iruí, Capané, and Minas do Leão), several outcrops display tidal bar records (Fritzen et al. 2019). In this study, the general arrangement of these depositional systems indicates that the longitudinal axis of the tide-dominated estuary is NE-SW, which is one of the main directions of the Paraná Basin structures (Zalán et al. 1990). Thus, according to the NE-basinward depositional model proposed, it is inferred that the estuarine system developed over the LST-1 fluvial systems deposits through a NE-SW lineament, probably in a paleovalley similar to the observed in Candiota (see in Fig. 1), where the confined morphology created conditions for tidal amplification and its propagation to inner regions.

In the Rio Bonito Formation, the main evidences indicating a tide depositional system are bidirectional paleocurrents indicators, heterolithic intercalations, tidal rhythmites, tidal bundles, mud drapes, and reactivation surfaces (e.g., Holz 2003, Lopes 2004, Fritzen et al. 2019). However, even without effective paleocurrent measurements due to the kind of data (boreholes) used in this work, the analysis of bidirectional ripples cross-lamination show an asymmetric bidirectional character, with frequency of approximated one to ten (1:10). Flood (or ebb) tidal flows dominance is used with regard to the net sediment transport. Thus, flood (or ebb) asymmetry does not imply flood (or ebb) dominance (Brown \& Davies 2010). On the other hand, it is possible to say that ebb and flood tidal flows do not have the same peak tidal current strength and duration.

According to the depositional evolutionary models proposed for the study area - stage 1 - (Fig. 11), the deposition of the Rio Bonito Formation began with a fluvial system and gravity-flow-deposits (thickness of the sucessions varies between 2 and $8 \mathrm{~m}$ ) overlaying the crystalline Precambrian basement. This interpretation of the initial deposition is similar to the one proposed by Holz (2003) for the Rio Bonito Formation in Candiota. Holz (2003), recognized "a minor alluvial fan system” dominated by gravity processes and traction currents in a few cores, mostly in those located in the proximities of paleohills. Although these deposits were not analyzed in detail due to the lack of data, their interpretation suggests a region of high relief, probably, available as the source area (provenance), at least during the early deposition of the unit. In that setting, debris flows could dominate the areas' upper portions, next to elevated areas, and changing to stream flows in the middle portion, both systematically discharging sediments into the little fluvial channels, each gravity-flow event. This supplying generates a downfan change from gravelly to sandy and muddy sediments toward the low gradient.

The basal portion of the unit, interpreted by Reis (2007) as bayhead delta, intertidal and central basin with some alluvial fan, floodplain and fluvial channel, was reinterpreted as gravity-flow-deposits, fluvial channels and overbank deposits due to a frequent finning-upward succession. Then, fluvial channels and overbank facies associations are interbedded with tidal mud and sand flats and tidal bars deposits. The fluvial portion of the transgressive system tracts commonly shows evidence of tidal influences (Shanley et al. 1992, Shanley \& McCabe 1993). The latter feature of the vertical profile also translates into an upward decrease in the degree of amalgamation of transgressive channel-fill sandstones, which are often described as isolated ribbons engulfed within floodplain fines (Shanley \& McCabe 1993). In summary, an undifferentiated style, fairly wet, fluvial environment was identified, presenting a few channels and many overbank deposits, followed by an environment with strong tide-fluvial interaction, characteristic of a transgressive context such as in the Rio Bonito Formation. In addition, both sandstones of fluvial channels and sand bars facies associations are mostly subarkoses, suggesting fluvial supply for the tidal sand bars, which probably had some portions constructed by fluvial sediments reworking. Fritzen et al. (2019) also found tide-fluvial interaction evidence in a local study of the Rio Bonito Formation in Candiota. Moreover, bioturbations are absent to very rare and of low intensity (mostly BI: 1) in fluvial channels and overbank facies associations, indicating a dynamic environmental condition unfavorable to most of the burrowing organisms. On the other hand, bioturbations are more usual and intense (mostly BI: 1-3) in all facies associations of the tide-dominated estuary depositional system, indicating considerable salinity condition and low sedimentation rates to support burrowing organisms in this loci, mainly in tidal mud and sand flats.

At the top, the general interpretation was similar to that of Reis (2007), in which a shallow-marine depositional system was developed, with dominance of fairweather waves, but with occurrences of storm events. In addition, horizontal and vertical bioturbations are very common and intense (mostly BI: 3-4) in this shallow-marine deposits, especially in lower shoreface-shelf transition facies association, indicating higher salinity levels and low-energy conditions (lower deposition rates), although erosion and rapid deposition were frequent due to storm events.

According to Zecchin et al. (2017), bedset boundaries are lag deposits associated to a context of little or absent facies change surrounding, therefore not associated with water-depth changes, but only with local variations (e.g., storm event). On the other 
hand, following those same authors, lag deposits delimiting wave-ravinement surfaces (WRV) are associated with significant changes of facies that represent shoreline shifts and are inserted within system tracts. Thus, $\mathrm{Gm}_{\mathrm{i}}$ facies was interpreted as a lag deposit, due to its occurrence in the upper portions of the described wells without sudden lateral changes of facies and could represent bedset boundaries related to the record of the most energetic events in shoreface settings (such as a storm event), positioned in the upper shoreface facies association. Therefore, this facies is a result of changes in wave-regime and sediment supply as well as of minor relative sea-level changes (Zecchin et al.2017). However, a WRV was also identified through a $15-\mathrm{cm}$-thick layer of $\mathrm{Gm}_{\mathrm{i}}$ facies that separates tidal sand bars and middle shoreface facies associations in the SG-04 well (45.9 m) and occurs in the middle of the TST-2, representing an erosional shoreface retreat.

The SU-1 subaerial unconformity identified was interpreted as equivalent to SB-3 by Holz et al. (2010), representing the first deposits of anchored directly upon the crystalline Precambrian basement. In contrast, SU-2 occurs approximately in the central portion of the cores when the estuarine system, represented by tidal sand bars, is over shallow-marine deposits. This surface marks an erosive event in a context of base level fall and destruction of accommodation without fluvial deposits.

Following the idea that the Rio Bonito Formation is inserted in a transgressive context, Holz (2003) and Reis (2007) identified parasequences that would represent the existence of smallscale cycles for Candiota and São Gabriel regions, respectively. However, according to Neal and Abreu (2009), the identification of a relatively conformable unit is dependent on data resolution and coverage and the stacking pattern repeats across a range of accommodation succession durations and magnitudes that permits construction of self-similar hierarchies. This study proposes a stratigraphic framework independent of time or sealevel terminology, flexible for all data scales which can be complexed with an improvement on data-resolution. Some possible high-resolution key stratigraphic surfaces were observed, though they are irregular and difficult to correlate (with the exception of SU-2). Therefore, the stratigraphic events were observed independent of scale and could be correlated, supporting the general idea of the stratigraphic sequence framework.

Cambaí Grande is an important outcrop of the Paraná Basin located in the city of São Gabriel (see Fig. 1; SAD69 UTM reference coordinate system; zone 22J, UTMX: 212421 mE; UTM Y: $301731 \mathrm{mS}$; and elevation: $140 \mathrm{~m}$ ), where several fossils have been recognized, such as Gangamopteris, Samaropsis, Cordaites, unidentified algae, and fructifications (Cazzulo-Klepzig et al. 1980, Cazzulo-Klepzig \& GuerraSommer 1985). Initially, the Cambaí Grande outcrop deposits were interpreted as the Upper Itararé Group (Corrêa da Silva 1978 to Guerra-Sommer \& Cazzulo-Klepzig 1993); however, Elias et al. (2000) have reevaluated this outcrop as belonging to the Rio Bonito Formation, since the correlations with cores of the region showed similar lithologies. Recently, Tybusch et al. (2016) confirmed for the first time the presence of Glossopteris-type leaves in the Cambaí Grande Paleoflora, which is common in the Rio Bonito Formation, supporting the new position of the Cambaí Grande Outcrop. In this study, plant remains were presented in most boreholes described in several sedimentary facies (Tab. 2), but it was not possible to identify some specific attribute; however, in agreement with Elias et al. (2000), our data also have good correspondence to the Cambaí Grande outcrop succession, and that exposition would be positioned probably between TST-1 and TST- 2 of the stratigraphic framework proposed (Fig. 12).

The member division of the Rio Bonito Formation in several regions of Rio Grande do Sul State is unclear, because the facies correspondent to each member are mixed, absent, or extremely dominant. This unclear member division certainly indicates a complex depositional pattern and lateral changes in the depositional environment that may have produced the interfingering of deposits with different characterictics, or reflets a thinner and condensed deposition near the basin edges. However, both Elias et al. (2000) — using lithology data - and Tybusch et al. (2016) - using paleontological data - have indicated the Cambaí Grande Outcrop as the upper-middle portion of the Rio Bonito Formation, probably as Paraguaçu Member. Thus, we think the Rio Bonito Formation deposits of São Gabriel City could also represent that member.

Subsidence and uplift events of the tectonic blocks were some of the main determinants of sedimentation in the Paraná Basin in large scale correlations along the Rio Bonito Formation (Holz et al. 2006). In this work, the control of system tracts' thickness, mainly along the strike-orientation (Fig. 12), allowed the inference of oscillations in relative sea-level as well as variation in accommodation rates linked to eustatic fluctuations and local tectonics during the early Permian.

The thicknesses variations of the systems tracts along the correlation section (Fig. 12) can be related to erosive events - mainly erosive surfaces like SU-1 and SU-2 - that could control the preservation of succession. These features generate dip and strike oriented differential preserved sections. It may represent not only regional erosive events but also local erosional settings related to the inherent depositional systems dynamics (e.g., upper shoreface environment). It is common specifically in wave-dominated systems, whereas wave reworking is recurrent and continuous along with deposition. And finally, tectonic controls may also have caused differential subsidence, resulting in the thinning or thickening of stratigraphic units. Overall, the interplay between these factors generates a complex grouping of possible controls for thicknesses variations on coastal, basin-border deposits such as in the Rio Bonito Formation.

\section{CONCLUSIONS}

- In São Gabriel, the Rio Bonito Formation was deposited in three paleoenvironmental stages, with predominance of (S1) a fluvial depositional system at the base, (S2) a tide-dominated estuary depositional system in the central portion and (S3) a wave-dominated shallow-marine system at the top. These stages represent the dominant depositional systems, but they can have several interdigitations;

- Throughout the succession, minor gravity-flows, fluvial channels and abundant overbank deposits compose the base 
of the cores. In sequence, muddy estuarine deposits were observed, with mud and sand flats, fluvial channel and overbank deposits occuring together, followed by a sandy estuarine system with the dominance of tidal sand bars. The estuarine system was most likely formed over a SW-NE lineament (probably within a paleovalley) in the Paraná Basin, in meso to macrotidal, with ebb and flood tidal currents of different peak strength and duration. Finally, the wave-dominated shallow-marine system is represented by the upper, middle and lower shorefaces in a coast with frequent storm events;

- The thicknesses variations along the systems tracts and from well to well may have occured due to regional erosions (subaerial unconformities - SU-1 and SU-2), or may be related to the local dynamic depositional based erosions and reworking events (mainly coastal wave driven). Also, tectonic (syn- to post-depositional) controls may have influenced, generating differential subsidence and consequently, the thinning or thickening of units.

- Local-scale stratigraphic correlations such as this study together with isotopic dating (e.g., Cagliari et al.
2014, Griffis et al. 2018) could be the key for future regional-scale stratigraphic correlations, providing a more accurate and consistent regional stratigraphic framework.

\section{ACKNOWLEDGEMENTS}

This study is part of R. Maahs's Master Degree dissertation by the Post-Graduate Program in Geosciences of the Federal University of Rio Grande do Sul. We thank the National Petroleum Agency (ANP) and the Brazilian Research Council $(\mathrm{CNPq})$ for their support, which made this project possible. We thank the Brazilian Geological Survey (CPRM) for allowing access to the cores and the publishing of the results. Also, we thank Editor-in-Chief Claudio Riccomini and two anonymous reviewers for their valuable comments and suggestions to improve the quality of this paper and Gabriela Veiga Alano Rodrigues, Natália Gauer Pasqualon, and Gabriel Daitzchman for helping in the English translation and organization of this paper.

\section{ARTICLE INFORMATION}

Manuscript ID: 20190059. Received on: 07/20/2019. Approved on: 10/10/2019.

R. M. participated in the whole study and wrote most part of the manuscript, including the construction of the figures and table. Also, he corrected the manuscript according to the reviewers' suggestions; J. K. participated in the description of boreholes, contributed to all parts of the study, wrote the Abstract and Introduction of the first draft, and revised and improved the manuscript; C. S. provided advisorship in the construction of the depositional model and the stratigraphic framework; R. A. prepared Figures 1 and 2 and provided advisorship in the construction of all others.

Competing interests: The authors declare no competing interests.

\section{REFERENCES}

Allen J.R.L. 1963. The classification of cross-stratified units, with notes on their origin. Sedimentology, 2(2):93-114. https://doi. org/10.1111/j.1365-3091.1963.tb01204.x

Bann K.L., Tye S.C., MacEachern J.A., Fielding C.R., Jone, B.G. 2008. Ichnological and sedimentologic signatures of mixed wave-and stormdominated deltaic deposits: Examples from the Early Permian Sydney Basin, Australia. In: Hampson G.J., Steel R.J., Burgess P.M., Dalrymple R.W. (eds.), Recent advances in models of siliciclastic shallow-marine stratigraphy. SEPM, Tulsa, Special Publication, 90, p. 293-332. https://doi.org/10.2110/ pec.08.90.0293

Best J.L., Bridge J.S. 1992. The morphology and dynamics of low amplitude bedwaves upon stage plane beds and the preservation of planar laminae. Sedimentology, 39(5):737-752.https://doi.org/10.1111/j.1365-3091.1992. tb02150.x

Bridge J.S. 2003. Rivers and Floodplains: forms, processes and sedimentar record. Oxford, Blackwell, $491 \mathrm{p}$.

Brown J.M., Davies A.G. 2010. Flood/ebb tidal asymmetry in a shallow sandy estuary and the impact on net sand transport. Geomorphology, 114(3):431-439. http://dx.doi.org/10.1016/j.geomorph.2009.08.006

Cagliari J., Lavina E.L.C., Philipp R.P., Tognoli F.M.W., Basei M.A.S., Faccini U.F. 2014. New Sakmarian ages for the Rio Bonito formation (Paraná Basin, southern Brazil) based on LA-ICP-MS U-Pb radiometric dating of zircons crystals. Journal of South American Earth Sciences, 56:265-277. http:// dx.doi.org/10.1016/j.jsames.2014.09.013

Cagliari J., Philipp R.P., Buso V.V., Guimarães Netto R., Hillebrand P.K., Lopes R. da C., Basei M.A.S., Faccini U.F. 2016. Age constraints of the glaciation in the Parana Basin: evidence from new U-Pb dates. Journal of Geological Society, 173(6):871-874. https://doi.org/10.1144/jgs2015-161
Catuneanu O. 2006. Principles of sequence stratigraphy. Amsterdam, Elsevier, $375 \mathrm{p}$.

Catuneanu O., Abreu V., Bhattacharya J.P., Blum M.D., Dalrymple R.W., Eriksson P.G., Fielding C.R., Fisher W.L., Galloway W.E., Gibling M.R., Giles K.A., Holbrook J.M., Jordan R., Kendall C.G.St.C., Macurda B., Martinsen O.J., Miall A.D., Neal J.E., Nummedal D., Pomar L., Posamentier H.W., Pratt B.R., Sarg J.F., Shanley K.W., Stell R.J., Strasser A., Tucker M.E., Winker C. 2009. Towards the standardization of sequence stratigraphy. Earth-Science Reviews, 92(1-2):1-33. https://doi.org/10.1016/j.earscirev.2008.10.003

Cazzulo-Klepzig M., Guerra-Sommer M. 1985. Relationship between the Taphoflora of the Itararé Group, Paraná Basin, South Brazil and the Permocarboniferous Boundary. In: Congresso Internacional de Estratigrafia y Geologia del Carbonífero, 10., Madrid. Comptes rendus... Madrid: IUGS, v. 2 , p. 395-408.

Cazzulo-Klepzig M., Guerra-Sommer M., Bossi E.G. 1980. Revisão fitoestratigráfica do Grupo Itararé no Rio Grande do Sul: I. Acampamento Velho, Cambaí Grande, Budó e Morro do Papaléo. Boletim Instituto de Geociências, 11:55-76.

Clifton H.E. 2006. A reexamination of facies models for clastic shorelines. In: Posamentier H.W., Walker R.G. (Eds.), Facies Models Revisited. Tulsa, Society for Sedimentary Geology, p. 293-336.

Collinson J.D. 1996. Alluvial sediments. In: Reading H.G. (Ed.), Sedimentary environments: processes, facies and stratigraphy. Oxford, Blackwell, v. 3, p. 37-82.

Collinson J.D., Mountney N., Thompson D.B. 2006. Sedimentary Structures. Hertfordshire, Terra Publishing, $292 \mathrm{p}$.

Collinson J.D., Thompson D.B. 1989. Sedimentary Structures. London, Unwin Hyman, v. 2, 207 p. 
Corrêa da Silva Z.C. 1978. Observações sobre o Grupo Tubarão no Rio Grande do Sul com especial destaque à estratigrafia da formação Itararé. Pesquisas em Geociências, 9(9):9-61. https://doi.org/10.22456/1807-9806.21779

Daemon R.F., Quadros L.P. 1970. Bioestratigrafia do Neopaleozóico da Bacia do Paraná. In: Congresso Brasileiro de Geologia, 24., Brasília. Anais... São Paulo: SBG, p. 359-412.

Dalrymple R.W. 2010. Tidal depositional systems. In: James N.P., Dalrymple R.W. (Eds.), Facies models 4. Newfoundland \& Labrador, Geological Association of Canada Publications, 4, p. 201-231.

Dalrymple R.W., Zaitlin B.A., Boyd R. 1992. Estuarine facies models: conceptual basis and stratigraphic implications. Journal of Sedimentary Research, 62(6):1130-1146. https://doi.org/10.1306/ D4267A69-2B26-11D7-8648000102C1865D

Dalrymple R.W., Zaitlin B.A., Boyd R. (Eds.). 1994. Incised Valley Systems: Origin and Sedimentary Sequences. SEPM, Special Publication 51., $391 \mathrm{p}$.

Duke W.L. 1985. Hummocky cross-stratification, tropical hurricanes and intense winter storms. Sedimentology, 32(2):167-194. https://doi. org/10.1111/j.1365-3091.1985.tb00502.x

Duke W.L., Arnott R.W.C., Cheel R.J. 1991. Shelf sandstones and hummocky cross-stratification: new insights on a stormy debate. Geology, 19(6):625-628. https://doi.org/10.1130/0091-7613(1991)019\%3C0625 :SSAHCS\%3E2.3.CO;2

Dumas S., Arnott R.W.C. 2006. Origin of hummocky and swaley crossstratification - the controlling influence of unidirectional current strength and aggradation rate. Geology, 34(12):1073-1076. https://doi. org/10.1130/G22930A.1

Elias A.R.D., Garcia A.J.V., Lavina E.L. 2000. Arcabouço cronoestratigráfico do Eopermiano da Bacia do Paraná na Região Centro-Oeste do Rio Grande do Sul. Pesquisas em Geociências, 27(2):31-44. https://doi. org/10.22456/1807-9806.20188

Foix N., Paredes J.M., Giacosa R.E. 2013. Fluvial architecture variations linked to changes in accomodation space: río chico formation (late paleocene), golfo san jorge basin, Argentina. Sedimentary Geology, 294:342-355. http://dx.doi.org/10.1016/j.sedgeo.2013.07.001

Fritzen M.R., Cagliari J., Candido M., Lavina E.L.C. 2019. Tidal bar cyclicity record in the Lower Permian: The Rio Bonito Formation, Paraná Basin, southern Brazil. Sedimentary Geology, 381:76-83. http://dx.doi. org/10.1016/j.sedgeo.2018.12.011

Griffis N.P., Mundil R., Montañez I.P., Isbell J., Fedorchuk N., Vesely F., Iannuzzi R., Yin Q.Z. 2018. A new stratigraphic framework built on $\mathrm{U}-\mathrm{Pb}$ single-zircon TIMS ages and implications for the timing of the penultimate icehouse (Paraná Basin, Brazil). Geological Society of America Bulletin, 130(5):848-858. http://doi.org/10.1130/B31775.1

Guerra-Sommer M., Cazzulo-Klepzig M. 1993. Biostratigraphy of the Southern Brazilian Neopalaeozoic Gondwana Sequence: a preliminary palaeobotanical approach. In: International Congrès de la Stratigraphie et Géologie du Carbonifère et Permien, 12., Buenos Aires. Comptes rendus... Buenos Aires: IUGS, v. 2, p. 61-72.

Harms J.C., Southard J.B., Spearing D.R., Walker R.G. 1975. Depositional environments as interpreted from primary sedimentary structures and stratification sequences. Short Course n. 2, SEPM, p. 161.

Harris P.T. 1988. Large-scale bedforms as indicators of mutually evasive sand transport and the sequential infilling of wide-mouthed estuaries. Sedimentary Geology, 57(3-4):273-298. https://doi. org/10.1016/0037-0738(88)90034-6

Holz M. 1995. O intervalo gonduânico basal (Eo-Permiano) da Bacia do Paraná na região nordeste do Rio Grande do Sul - um exercício de Estratigrafia. $\mathrm{PhD}$ Thesis, Universidade Federal do Rio Grande do Sul, Porto Alegre, 255 p.

Holz M. 2003. Sequence stratigraphy of a lagoonal estuarine systeman example from the lower Permian Rio Bonito Formation, Paraná Basin, Brazil. Sedimentary Geology, 162(3):305-331. http://dx.doi.org/10.1016/ S0037-0738(03)00156-8

Holz M., Carlucci R. 2000. Litoestratigrafia, Estratigrafia de Seqüências e Evolução Paleofisiográfica da zona de borda da Bacia do Paraná no Rio Grande do Sul durante o Eo-Permiano. In: Holz M., De Ros L.F. (Eds.), Geologia do Rio Grande do Sul. Porto Alegre, CIGO/UFRGS, p. 303-322.
Holz M., França A.B., Souza P.A., Iannuzzi R., Rohn R. 2010. A stratigraphic chart of the Late Carboniferous/Permian succession of the eastern border of the Paraná Basin, Brazil, South America. Journal of South American Earth Sciences, 29(2):381-399. https://doi.org/10.1016/j.jsames.2009.04.004

Holz M., Küchle J., Philipp R.P., Bischoff A.P., Arima N. 2006. Hierarchy of tectonic control on stratigraphy signatures: base-level changes during the Early Permian in the Paraná Basin, southernmost Brazil. Journal of South American Earth Sciences, 22(3):185-204. http://dx.doi.org/10.1016/j. jsames.2006.09.007

Lavina E.L., Lopes R.C. 1987. A transgressão marinha do Permiano Inferior e a evolução paleogeográfica do Super-Grupo Tubarão no Estado do Rio Grande do Sul. Paula Coutiana, 1:51-103.

Lopes R.C. 2004. Arquitetura Deposicional e Potencial de Armazenamento em Arenitos Associados às Jazidas de Carvão da Formação Rio Bonito na Região do Rio Jacuí, Rio Grande do Sul. PhD Thesis, Universidade do Vale do Rio dos Sinos, Porto Alegre, $257 \mathrm{p}$.

McCabe P.J. 1985. Depositional environments of coal and coal-bearing strata. In: Rahmani R.A., Flores R.M. (Eds.), Sedimentology of coal and coalbearing sequences. Oxford, IAS, Special Publication, 7, p.13-42.

McCormick D.S., Grotzinger J.P. 1993. Distinction of marine from alluvial Facies in the Paleoproterozoic (1.9 Ga) burnside formation, Kilohigok basin, NWT, Canada. Journal of Sedimentary Research, 63(3):398-419. https://doi.org/10.1306/D4267B13-2B26-11D7-8648000102C1865D

Miall A.D. 2006. The Geology of Fluvial Deposits: Sedimentary Facies, Basin Analysis, and Petroleum Geology. Berlin, Springer, $582 \mathrm{p}$.

Milani E.J. 1997. Evoluçao tectono-estratigráfica da Bacia do Paraná e seu relacionamento com a geodinâmica fanerozóica do Gondwana sul-ocidental. $\mathrm{PhD}$ Thesis, Universidade Federal do Rio Grande do Sul, Porto Alegre, 225 p.

Milani E.J. 2000. Geodinâmica fanerozóica do Gondwana sul-ocidental e a evolução geológica da Bacia do Paraná. In: Holz M., De Ros L.F. (Eds.), Geologia do Rio Grande do Sul. Porto Alegre, CIGO/UFRGS, p. 275-302.

Milani E.J. França A.B., Schneider R.L. 1994. Bacia do Paraná. Boletim de Geociências da Petrobras, 8:69-82.

Milani E.J., Melo J.H.G. de, Souza P.A. de, Fernandes L.A., França A.B. 2007. Bacia do Paraná. Boletim de Geociências da Petrobras, 15(2):265-287.

Mori A.L.O., Souza P.A. de, Marques J.C., Lopes R. da C. 2012. A new $\mathrm{U}-\mathrm{Pb}$ age dating and palynological data from a Lower Permian section of the southernmost Paraná Basin, Brazil: Biochronostratigraphical and geochronological implications for Gondwana correlations. Gondwana Research, 21(2-3):654-669. https://doi.org/10.1016/j. gr.2011.05.019

Neal J., Abreu V. 2009. Sequence stratigraphy hierarchy and the accommodation succession method. Geology, 37(9):779-782. http://doi. org/10.1130/G25722A.1

Nemec W., Postma G. 1993. Quaternary alluvial fans in southerwestern Crete: sedimentation processes and geomorphic evolution. In: Marzo M., Puigdefabregas C. (Eds.), Alluvial Sedimentation. Oxford, IAS, 17, p. 235-276.

Olariu C., Steel R.J., Dalrymple R.W., Gingras M.K. 2012. Tidal dunes versus tidal bars: The sedimentological and architectural characteristics of compound dunes in a tidal seaway, the lower Baronia Sandstone (Lower Eocene), Ager Basin, Spain. Sedimentary Geology, 279:134-155. https:// doi.org/10.1016/j.sedgeo.2012.07.018

Plint A.G. 2010. Wave- and storm-dominated shoreline and shallowmarine systems. In: James N.P., Dalrymple R. W. (Eds.), Facies models 4. Newfoundland \& Labrador, Geological Association of Canada Publications, 4, p. 167-199.

Reis P.D. 2007. Caracterização, análise e modelagem tridimensional de corpos reservatórios em ambientes parálicos no intervalo Eo-permiano da Bacia do Paraná - região de São Gabriel, RS. Undergraduate Monograph, Universidade Federal do Rio Grande do Sul, Porto Alegre, 192 p.

Rocha-Campos A.C., Basei M.A.S., Nutman A.P., Santos P.R. 2006. SHRIMP $\mathrm{U}-\mathrm{Pb}$ zircon geochronological calibration of the paleozoic supersequence, Paraná Basin, Brazil. In: South American Symposium on Isotope Geology, 5. Punta del Este. Anais... Buenos Aires: Idea Gráfica, p. 298-301. 
Roep T.H.B., Beets D.J., Dronkert H., Pagnier H. 1979. A prograding coastal sequence of wave-built structures of Messinian age, Sorbas, Almeria, Spain. Sedimentary Geology, 22(3-4):135-163. https://doi. org/10.1016/0037-0738(79)90050-2

Rogers D.A., Astin T.R. 1991. Ephemeral lakes, mud pellets and windblown sand and silt: reinterpretations of Devonian lacustrine cycles in north Scotland. In: Anadon P., Cabrera L.L., Kelts K. (Eds.), Lacustrine Facies Analysis. Special Publication n. 13, IAS, p. 199-222.

Schneider R.L., Muhlmann H., Tommasi I.E., Medeiros R.S., Daemon R.F., Nogueira A.A. 1974. Revisão estratigrafica da Bacia do Parana. In: Congresso Brasileiro de Geologia, 28., Porto Alegre. Anais ... São Paulo: SBG, p. 41-66.

Shanley K.W., McCabe P.J. 1993. Alluvial architecture in a sequence stratigraphic framework: a case history from the Upper Cretaceous of southern Utah, U.S.A. In: Flint S., Bryant I. (Eds.), Quantitative Modeling of Clastic Hydrocarbon Reservoirs and Outcrop Analogues. Special Publication n. 15., IAS, p. 21-55.

Shanley K.W., McCabe P.J., Hettinger R.D. 1992. Tidal influence in Cretaceous fluvial strata from Utah, USA: a key to sequence stratigraphic interpretation. Sedimentology, 39(5):905-930. https://doi. org/10.1111/j.1365-3091.1992.tb02159.x

Shanmugam G., Poffenberger M., Toro Alava, J. 2000. Tide-dominated estuarinefaciesintheHollinandNapo("T" and “ $U$ ") formations (Cretaceous), Sacha Field, Oriente Basin, Ecuador. AAPG Bulletin, 84(5):652-682. http:// dx.doi.org/10.1306/C9EBCE7D-1735-11D7-8645000102C1865D

Souza P.A., Marques-Toigo M. 2005. Progress on palynostratigraphy of the permian strata in Rio Grande do Sul state, Paraná Basin, Brazil.
Anais da Academia Brasielira de Ciências, 77(2):353-365. http://dx.doi. org/10.1590/S0001-37652005000200012

Tybusch G.P., Iannuzzi R., Bernardes-de-Oliveira M.E.C., Lopes R.C. 2016. Revaluation of the Glossopterids from the lower Permiano of Cambaí Grande Outcrop, Paraná Basin, RS. Geologia USP, Série Científica, 16(4):41-51. https://doi.org/10.11606/issn.2316-9095.v16i4p41-51

Visser M.J. 1980. Neap-spring cycles reflected in Holocene subtidal large-scale bedform deposits: a preliminary note. Geology, 8(11):543-546. https://doi. org/10.1130/0091-7613(1980)8\%3C543:NCRIHS\%3E2.0.CO;2

Walker R.G., Plint A.G. 1992. Wave- and storm-dominated shallow marine systems. In: Walker R.G., James N.P. (Eds.). Facies Models - Response to Sea Level Change. Newfoundland, Geological Association of Canada Publications, p. 219-238.

Wildner W., Ramgrab G.E., Lopes R.D., Iglesias C.D.F. 2008. Geologia e recursos minerais do estado do Rio Grande do Sul: escala 1:750.000. Porto Alegre: CPRM.

Zalán P.V., Wolff S., Conceição J.D.J., Marques A., Astolfi M.A.M., Vieira I.S., Zanotto O.A. 1990. Bacia do Paraná. In: Gabaglia G.P.R., Milani E.J. (Coords.), Origem e Evolução das Bacias Sedimentares. Rio de Janeiro, Petrobras, p. 135-168.

Zecchin M., Caffau M., Catuneanu O., Lenaz D. 2017. Discrimination between wave-ravinement surfaces and bedset boundaries in Pliocene shallow-marine deposits, Crotone Basin, southern Italy: An integrated sedimentological, micropalaeontological and mineralogical approach Sedimentology, 64(7):1755-1791. https://doi.org/10.1111/sed.12373 